\title{
FABP3 in the Anterior Cingulate Cortex Modulates the Methylation Status of the Glutamic Acid Decarboxylase ${ }_{67}$ Promoter Region
}

\author{
Yui Yamamoto, ${ }^{1,2}$ Hiroyuki Kida, ${ }^{3}$ Yoshiteru Kagawa, ${ }^{1}$ Yuki Yasumoto, ${ }^{1}$ Hirofumi Miyazaki, ${ }^{1}$ Ariful Islam, ${ }^{1}$ \\ Masaki Ogata, ${ }^{1,2}$ Yuchio Yanagawa, ${ }^{4}$-Dai Mitsushima, ${ }^{3}$ Kohji Fukunaga, ${ }^{5}$ and Yuji Owada ${ }^{1}$ \\ ${ }^{1}$ Department of Organ Anatomy, Tohoku University, Sendai 980-8575, Japan, ${ }^{2}$ Department of Anatomy, Tohoku Medical and Pharmaceutical University, \\ Sendai 983-8536, Japan, ${ }^{3}$ Department of System Neuroscience, Yamaguchi University, Ube 755-8505, Japan, ${ }^{4}$ Department of Genetic and Behavioural \\ Neuroscience, Gunma University, Maebashi 371-8511, Japan, and 5Department of Pharmacology, Graduate School of Pharmaceutical Sciences, Tohoku \\ University, Sendai 980-8578, Japan
}

Polyunsaturated fatty acids (PUFAs) are essential for brain development and function. Increasing evidence has shown that an imbalance of PUFAs is associated with various human psychiatric disorders, including autism and schizophrenia. Fatty acid-binding proteins (FABPs), cellular chaperones of PUFAs, are involved in PUFA intracellular trafficking, signal transduction, and gene transcription. In this study, we show that FABP3 is strongly expressed in the GABAergic inhibitory interneurons of the male mouse anterior cingulate cortex (ACC), which is a component of the limbic cortex and is important for the coordination of cognitive and emotional behaviors. Interestingly, Fabp3 $\mathrm{KO}$ male mice show an increase in the expression of the gene encoding the GABA-synthesizing enzyme glutamic acid decarboxylase 67 (Gad67) in the ACC. In the ACC of Fabp3 K0 mice, Gad67 promoter methylation and the binding of methyl-CpG binding protein 2 (MeCP2) and histone deacetylase 1 (HDAC1) to the Gad67 promoter are significantly decreased compared with those in WT mice. The abnormal cognitive and emotional behaviors of Fabp3 KO mice are restored by methionine administration. Notably, methionine administration normalizes Gad67 promoter methylation and its mRNA expression in the ACC of Fabp3 KO mice. These findings demonstrate that FABP3 is involved in the control of DNA methylation of the Gad67 promoter and activation of GABAergic neurons in the ACC, thus suggesting the importance of PUFA homeostasis in the ACC for cognitive and emotional behaviors.

Key words: ACC; FABP3; GABA; GAD67; parvalbumin; PUFA

\section{Significance Statement}

The ACC is important for emotional and cognitive processing. However, the mechanisms underlying its involvement in the control of behavioral responses are largely unknown. We show the following new observations: (1) FABP3, a PUFA cellular chaperone, is exclusively expressed in GABAergic interneurons in the ACC; (2) an increase in Gad67 expression is detected in the ACC of Fabp3 KO mice; (3) the Gad67 promoter is hypomethylated and the binding of transcriptional repressor complexes is decreased in the ACC of Fabp3 KO mice; and (4) elevated Gad67 expression and abnormal behaviors seen in Fabp3 KO mice are mostly recovered by methionine treatment. These suggest that FABP3 regulates GABA synthesis through transcriptional regulation of Gad67 in the ACC.

\section{Introduction}

The anterior cingulate cortex (ACC) is a component of the limbic system. The ACC is particularly important for emotional and

\section{Received May 21, 2018; revised Sept. 17, 2018; accepted 0ct. 9, 2018}

Author contributions: Y. Yamamoto and Y.0. wrote the first draft of the paper; Y. Yamamoto and Y.0. edited the paper; Y. Yamamoto, H.K., Y. Yanagawa, D.M., K.F., and Y.O. designed research; Y. Yamamoto, H.K., Y.K., Y. Yasumoto, H.M., A.I., M.O., Y. Yanagawa, D.M., K.F., and Y.O. performed research; Y. Yamamoto analyzed data; Y. Yamamoto and Y.0. wrote the paper.

This work was supported in part by Japan Society for the Promotion of Science Grant KAKENHI 16 H05116 to Y.O. and 16K18366 to Y. Yamamoto; and in part by the Project of Translational and Clinical Research Core Centers from cognitive processing (Bush et al., 2000) and is reciprocally connected to areas important for emotional conflict (e.g., the

AMED of Japan JP17dm0107071 to K.F. We thank Dr. Kazuhito Yamaguchi, Tomoo Sawada, and Nobuko Tokuda (Department of Organ Anatomy, Yamaguchi University) for many helpful discussions and suggestions.

The authors declare no competing financial interests.

Correspondence should be addressed to either of the following: Dr. Yuji Owada, Seiryo-machi Aoba-ku, Sendai 980-8575, Japan, E-mail: owada@med.tohoku.ac.jp; or Dr. Yui Yamamoto, Fukumuro Miyagino-ku, Sendai 983 8536, Japan, E-mail: yuiyama@tohoku-mpu.ac.jp.

https://doi.org/10.1523/JNEUROSCI.1285-18.2018

Copyright $\odot 2018$ the authors $\quad 0270-6474 / 18 / 3810411-13 \$ 15.00 / 0$ 
amygdala $[\mathrm{AM}]$ ), working memory (e.g., the hippocampus), cognition (e.g., the PFC), and pain processing (e.g., the hypothalamus) (Devinsky et al., 1995; Bush et al., 2000). In rodents and nonhuman primates, the ACC has been associated with the regulation of aversive behavior to noxious stimuli (Johansen et al., 2001; Johansen and Fields, 2004), reward-based decision-making (Amemori and Graybiel, 2012), and remote memory (Frankland et al., 2004) based on pharmacological inactivation, microstimulation, and lesion studies. In humans, studies using fMRI indicate that hypoactivity of the ACC is associated with several neuropsychiatric diseases, including attention deficit hyperactivity disorder (Bush et al., 1999), conduct disorder (Stadler et al., 2007), and autism spectrum disorders (Di Martino et al., 2009). However, the mechanisms that underlie the involvement of the ACC in the control of behavioral responses and the pathology of neuropsychiatric diseases are largely unknown.

Fatty acid-binding proteins (FABPs) are intracellular, lowmolecular-weight $(14-15 \mathrm{kDa})$ polypeptides that are key molecules in the uptake, transport, and storage of long-chain fatty acids (Furuhashi and Hotamisligil, 2008; Liu et al., 2008). To date, 10 members of the FABP family have been recognized in mammals; these are expressed in different organs, tissues, and cell types with spatial heterogeneity. FABP3, FABP5, and FABP7 are expressed in the CNS (Owada et al., 1996): FABP5 and FABP7 are predominantly expressed in glial cells, whereas FABP3 is expressed in various types of neurons in the adult brain (Owada et al., 1996).

FABP3, which preferentially binds to $n-6$ polyunsaturated fatty acids (PUFAs), such as arachidonic acid, is expressed in the brain, heart, skeletal muscle, lactating mammary gland, and placenta (Watanabe et al., 1993; Islam et al., 2014). We recently determined that Fabp3 $\mathrm{KO}$ mice show enhanced haloperidolinduced catalepsy (Shioda et al., 2010) and $\alpha$-synuclein oligomerization in the basal ganglia (Shioda et al., 2014), which suggests a role of FABP3 in the control of dopaminergic function, as well as its involvement in the pathology of Parkinson's disease. Furthermore, we also showed that Fabp3 KO mice exhibit decreased novelty-seeking behavior (Shimamoto et al., 2014), which is closely associated with ACC function alterations (Weible et al., 2009). However, it remains unclear how FABP3 regulates ACC-related behaviors and synaptic functions in the ACC.

Changes in DNA methylation status in the PFC, including the ACC, affect various behaviors. Region-specific overexpression or knockdown of DNA methyltransferase (DNMT) in the mPFC of mice renders them behaviorally anxiolytic or anxiogenic, respectively (Elliott et al., 2016). Moreover, chronic intra-ACC infusion of DNMT inhibitors after contextual fear training prevents the expression of remote memories via a decrease in the DNA methylation of the memory suppressor gene in the ACC (Miller et al., 2010; Bali et al., 2011). This evidence suggests that DNA methylation is critical for emotional behavior and remote memory formation. However, the molecular basis and significance of the epigenetic control of ACC function remain unknown.

In the present study, we examined the detailed localization of FABP3 in the ACC of adult mice and explored its role using Fabp3 $\mathrm{KO}$ mice. We determined that FABP3 was expressed by parvalbumin-positive $\left(\mathrm{PV}^{+}\right)$GABAergic interneurons in the ACC and that Fabp3 $\mathrm{KO}$ mice exhibited increased glutamic acid decarboxylase 67 (Gad67) mRNA levels in the ACC. Moreover, Gad67 promoter hypomethylation in the ACC of Fabp3 KO mice was successfully restored following methyl donor treatment. Our findings demonstrate that FABP3 plays a critical role in cognitive and emotional behaviors through its regulation of Gad67 promoter methylation in the ACC.

\section{Materials and Methods}

Animals. Twelve-week-old C57BL/6 WT, homozygous Fabp3 KO (Binas et al., 1999), and Gad67-GFP knock-in mice (Tamamaki et al., 2003) were used in this study. Mice were housed under climate-controlled conditions with a $12 \mathrm{~h}$ light/dark cycle and were provided standard food and water ad libitum. All experimental protocols were approved by the Ethics Committee for Animal Experimentation of the Yamaguchi University Graduate School of Medicine and Tohoku University Graduate School of Medicine and were performed according to the Guidelines for Animal Experimentation of each institute under the law and notification requirements of the Japanese government.

$R T-P C R$ and $q R T-P C R$. Areas that encompass the ACC were carefully dissected from WT and Fabp3 KO mice (12-week-old male mice, $n=6$ per genotype) and were immediately frozen in liquid nitrogen. Total RNA was isolated using the RNeasy Mini Kit (QIAGEN) and reversetranscribed using the First Strand cDNA Synthesis Kit (Roche Diagnostics). For RT-PCR analysis, the following primers were used: Fabp3, 5'-CATGAAGTCACTCGGTGTGG-3' (forward) and 5'-TGCCATGA GTGAGAGTCAGG-3' (reverse); and $\beta$-Actin, $5^{\prime}$-CAGGAGATGGCC ACTGCCGCA- $3^{\prime}$ (forward) and $5^{\prime}$-CTCCTTCTGCATCCTGTCAG CA-3' (reverse). The PCR program was as follows: $94^{\circ} \mathrm{C}$ denaturation for $4 \mathrm{~min}$, followed by 25 cycles of $94^{\circ} \mathrm{C}$ for $1 \mathrm{~min}, 60^{\circ} \mathrm{C}$ for $1 \mathrm{~min}$, and $72^{\circ} \mathrm{C}$ for $1 \mathrm{~min}$. PCR products were electrophoresed on a $1.5 \%$ agarose gel, and gel images were digitally captured with the BioDoc-It Imaging System (UVP). For qPCR analysis, the gene expression of each cDNA sample was analyzed using TaqMan Probe reagent on a Step One Plus thermal cycler (Applied Biosystems) according to the manufacturer's protocol. The following TaqMan probes were used: Gad67, Mm00725661_s1; Fabp3, Mm00725661_s1; and Gapdh, Mm 03302249_g1. Gene expression levels were calculated and standardized using the $\Delta \Delta \mathrm{Ct}$ method and Gapdh gene expression levels as an internal control.

Histological examination. Mice were transcardially perfused with PBS, $\mathrm{pH} 7.4$, followed by perfusion with 4\% PFA in PBS under isoflurane anesthesia. The brains were removed, postfixed with the same fixative overnight at $4^{\circ} \mathrm{C}$, cryoprotected with graded sucrose (10\%, 20\%, and $30 \%$ for $\sim 12 \mathrm{~h}$ each), and stored at $-80^{\circ} \mathrm{C}$. Serial coronal sections $40 \mu \mathrm{m}$ thick were prepared using a CM1850 cryostat (Leica Microsystems).

For immunofluorescence staining, the sections were incubated as follows: 30 min in PBS, pH 7.4, containing 0.3\% Triton X-100; 1 h in PBS containing $5 \%$ normal goat serum (blocking solution); and overnight with various primary antibodies in blocking solution. The primary antibodies included mouse monoclonal antibodies against FABP3 (1:200, Hycult Biotechnology HM2016, RRID:AB_533050); rabbit polyclonal antibodies against neurogranin (Ng, 1:2000, Millipore AB5620, RRID: AB_91937); rabbit polyclonal antibodies against PV (1:2000, Abcam ab11427, RRID:AB_298032); rat monoclonal antibodies against somatostatin (SOM, 1:50, Millipore MAB354, RRID:AB_2255365); and rabbit polyclonal antibodies against calretinin (CR, 1:2000, Swant CR7697, RRID:AB_2619710). The sections were subsequently incubated with AlexaFluor-488- or 594-conjugated secondary antibody (1:500, Invitrogen) against mouse IgG, rabbit IgG, or rat IgG. After counterstaining of nuclei with DAPI, the slides were covered with Fluoromount (Diagnostic BioSystems K024) and observed under an LSM780 confocal laser microscope (Carl Zeiss). The position of the ACC was identified based on the atlas of Paxinos and Franklin (2004).

Western blot analysis. Western blotting analysis was performed as previously described (Yamamoto et al., 2009, 2013). Mouse brains were rapidly removed and perfused in ice-cold buffer $(0.32 \mathrm{M}$ sucrose, $20 \mathrm{~mm}$ Tris- $\mathrm{HCl}, \mathrm{pH}$ 7.4) for $3 \mathrm{~min}$. The ACC, mPFC, or AM tissues were dissected and homogenized in buffer containing $50 \mathrm{~mm}$ Tris- $\mathrm{HCl}, \mathrm{pH} 7.4$, 0.5\% Triton X-100, 4 mm EGTA, 10 mм EDTA, $1 \mathrm{~mm} \mathrm{Na}_{3} \mathrm{VO}_{4}, 40 \mathrm{~mm}$ sodium pyrophosphate, $50 \mathrm{~mm} \mathrm{NaF}, 100 \mathrm{~nm}$ calyculin A, $50 \mu \mathrm{g} / \mathrm{ml}$ leupeptin, $25 \mu \mathrm{g} / \mathrm{ml}$ pepstatin A, $50 \mu \mathrm{g} / \mathrm{ml}$ trypsin inhibitor, and $1 \mathrm{~mm}$ DTT. Supernatants were obtained after centrifugation, and the protein concentration was determined using a BCA Protein Assay Kit (Thermo Fisher Scientific). Samples were boiled for $3 \mathrm{~min}$ in Laemmli sample 
buffer and subjected to SDS-PAGE. Proteins were transferred onto an Immobilon PVDF membrane (Millipore) for $2 \mathrm{~h}$ at $70 \mathrm{~V}$; the membrane was treated with TTBS solution (50 mm Tris- $\mathrm{HCl}, \mathrm{pH} 7.5,150 \mathrm{~mm} \mathrm{NaCl}$, and $0.1 \%$ Tween 20 ) containing $2.5 \% \mathrm{BSA}$ for $1 \mathrm{~h}$ at $25^{\circ} \mathrm{C}$ and incubated overnight at $4^{\circ} \mathrm{C}$ with primary antibody solution. The following antibodies were used: mouse monoclonal anti-GAD67 (1:2000, Sigma-Aldrich G5419, RRID:AB_261978), anti-GAD65 (1:10,000, Sigma-Aldrich SAB4200232, RRID:AB_10762670), anti-gephyrin (1:5000, Synaptic Systems 147 111, RRID:AB_887719), anti-synaptophysin (1:1000, Sigma-Aldrich S5768, RRID:AB_477523), anti-phospho-calcium/ calmodulin-dependent protein kinase IV (CaMKIV; 1:1000) (Kasahara et al., 1999), anti-total-CaMKIV (1:1000) (Kasahara et al., 1999), anti- $\beta$ actin (1:5000, Santa Cruz Biotechnology sc-47778, RRID:AB_2714189), anti- $\beta$-tubulin (1:5000, Santa Cruz Biotechnology sc-58886, RRID: AB_793550), rabbit monoclonal anti-BDNF (1:10,000, Abcam ab108319, RRID:AB_10862052), rabbit polyclonal anti-vesicular GABA transporter (VGAT; 1:1000, Synaptic Systems 131003, RRID: AB_887869), anti-postsynaptic density-95 (PSD95; 1:1000, Cell Signaling Technology 3450, RRID:AB_2292883), anti-methyl-CpG binding protein 2 (MeCP2; 1:1000, Abcam ab2828, RRID:AB_2143853), antihistone deacetylase 1 (HDAC1; 1:1000, Millipore 17-101199, RRID: AB_11203477), anti-phospho-cAMP-responsive-element-binding protein (CREB; 1:1000, Millipore 05-807, RRID:AB_310017), anti-FABP3 (1: 500, ProteinTech 10676-1-AP, RRID:AB_2102309), guinea pig polyclonal anti-vesicular glutamate transporter 1 (VGLUT1; 1:5000, Millipore AB5905, RRID:AB_2301751), and anti-GABA $A_{A}$ receptor $\alpha 1$ subunit $\left(\mathrm{GABA}_{\mathrm{A}} \mathrm{R}, 1: 10,000\right.$, Frontier Institute GP-Af440, RRID:AB_2571572). After washing with TTBS, the membrane was treated with secondary antibody, and the reaction was analyzed using Imager 600 (GE Healthcare).

Measurement of brain GABA, dopamine (DA), serotonin (5-HT), and glutamate concentrations. Brain GABA, DA, and 5-HT concentrations were determined using commercial ELISA kits (BA E-2600; BA E-5900; BA E-5300, LDN) according to the manufacturer's instructions. The mice were killed by decapitation, and the ACC, mPFC, and AM were rapidly dissected on an ice-cold plate, frozen, and stored at $-80^{\circ} \mathrm{C}$ until use. On the day of analysis, total proteins from WT and Fabp3 KO mice were extracted using lysis buffer (10 mm Tris, pH 7.4, 5 mM EDTA, $0.1 \%$ SDS, $0.5 \%$ deoxycholate, and $0.5 \%$ NP40). Protein concentrations were measured using the BCA Protein Assay Kit (Thermo Fisher Scientific). For ELISA measurements, the sample volume was normalized using 100 $\mu \mathrm{g}$ of protein.

Microdialysis studies were performed as described previously (Shioda et al., 2010; Yamamoto et al., 2013). A guide cannula (AG-4, Eicom) was inserted into the ACC under anesthesia (1.5\% halothane, Takeda Chemical Industries) at the position $1 \mathrm{~mm}$ anterior to the bregma, $0.5 \mathrm{~mm}$ lateral to the midline, and $0.5 \mathrm{~mm}$ ventral from the dura surface according to the atlas of Paxinos and Franklin (2004). Twenty-four hours after recovery, microdialysis probes (A-I-4-02, dialysis membrane: $2 \mathrm{~mm}$ long, outer diameter: $0.22 \mathrm{~mm}$, Eicom) were inserted. Microdialysis was performed using a fully automated online system in HTEC-500GAA (Eicom) for glutamate analyses in freely moving mice. The microdialysis probe was perfused with Ringer's solution ( $1.3 \mathrm{~mm} \mathrm{CaCl}_{2}, 3 \mathrm{~mm} \mathrm{KCl}, 146$ $\mathrm{mm} \mathrm{NaCl}$, and $1 \mathrm{~mm} \mathrm{MgSO}_{4}$ ) at a $2.0 \mu \mathrm{l} / \mathrm{min}$ flow rate using a microsyringe pump (ESP-64, Eicom) over the entire period. The $\mathrm{KCl}$-induced glutamate concentration was measured in the acute phase with an increased $\mathrm{KCl}$ content $\left(1.3 \mathrm{~mm} \mathrm{CaCl}_{2}, 146 \mathrm{~mm} \mathrm{KCl}, 3 \mathrm{~mm} \mathrm{NaCl}\right.$, and $1 \mathrm{~mm}$ $\mathrm{MgSO}_{4}$ ) at a flow rate of $2.0 \mu \mathrm{l} / \mathrm{min}$ using a microsyringe pump (ESP-64, Eicom) for a 20 min period and was subsequently replaced with normal Ringer's solution. Dialysates were collected every $19.5 \mathrm{~min}$ in the sample loop of an auto-injector (EAS-20, Eicom) and then analyzed by HPLC with electrochemical detection (HTEC-500, Eicom).

Cells and transfection. Mouse neuroblastoma Neuro-2A (ATCC CCL131, RRID:CVCL_0470) cells were maintained in DMEM (SigmaAldrich) supplemented with $2 \mathrm{~mm}$ L-glutamate and $10 \% \mathrm{FBS}$ at $37^{\circ} \mathrm{C}$ under $5 \% \mathrm{CO}_{2}$. Neuro-2a cells were plated in $35 \mathrm{~mm}$ dishes, cultured in standard medium for $48 \mathrm{~h}$, and transfected using Lipofectamine 2000 (Invitrogen) for plasmid transfection and Lipofectamine RNAiMAX (Invitrogen) for siRNA transfection according to the manufacturer's protocols. The culture medium was changed to the standard medium, and cells were cultured for an additional $24 \mathrm{~h}$. Cell differentiation was initiated by serum starvation. After $24 \mathrm{~h}$ of incubation, cells were harvested and subjected to qPCR, Western blotting, and S-adenosyl methionine (SAM) ELISA.

Electrophysiological recordings. Brain slices $(350 \mu \mathrm{m})$ containing the ACC were prepared from 10- to 12-week-old mice as previously described (Mitsushima et al., 2013; Ebrahimi et al., 2016; Kida et al., 2016). The slices were incubated in a physiological solution containing the following: $118 \mathrm{~mm} \mathrm{NaCl}, 2.5 \mathrm{~mm} \mathrm{KCl}, 26 \mathrm{~mm} \mathrm{NaHCO}_{3}, 1 \mathrm{~mm} \mathrm{NaH}_{2} \mathrm{PO}_{4}, 10$ mu glucose, $4 \mathrm{~mm}_{\mathrm{MgCl}_{2}}, 4 \mathrm{~mm} \mathrm{CaCl}_{2}$, pH 7.4 (saturated with $95 \%$ $\mathrm{O}_{2} / 5 \% \mathrm{CO}_{2}$ ). For miniature response recordings, we used a physiological solution containing $0.5 \mu \mathrm{M}$ tetrodotoxin to block $\mathrm{Na}^{+}$channels. Patchrecording pipettes $(4-7 \mathrm{M} \Omega$ ) were filled with modified intracellular solution $(127.5 \mathrm{~mm}$ cesium methane sulfonate, $7.5 \mathrm{~mm} \mathrm{CsCl}, 10 \mathrm{~mm}$ HEPES, $2.5 \mathrm{~mm} \mathrm{MgCl}_{2}$, 4 mM Na 2 ATP, 0.4 mM Na 3 GTP, 10 mM sodium phosphocreatine, $0.6 \mathrm{~mm}$ EGTA, $\mathrm{pH}$ 7.25) to adjust the reversal potential of the $\mathrm{GABA}_{\mathrm{A}}$ receptor response. Whole-cell recordings were obtained from pyramidal neurons in the ACC with an Axopatch-700B amplifier (Molecular Devices). We analyzed the frequency and amplitude of mEPSCs and mIPSCs $>10 \mathrm{pA}$. After recording, we confirmed that mEPSCs and mIPSCs were completely abolished by $10 \mu \mathrm{M}$ CNQX (Sigma-Aldrich) and $10 \mu \mathrm{m}$ bicuculline methiodide (Sigma-Aldrich), respectively.

Chromatin immunoprecipitation (ChIP). ChIP assays were performed using the Magna ChIP G Tissue Kit (Millipore) according to the manufacturer's protocol. Briefly, after crosslinking with $1 \%$ formaldehyde, chromatin was sheared using the ChIP-IT Express Enzymatic Shearing Kit (Active Motif) into fragments of 200-1000 bp. Sheared chromatin was immunoprecipitated using Protein G magnetic beads and conjugated with $5 \mu \mathrm{g}$ ChIP-grade antibodies against MeCP2 (Abcam) or HDAC1 (Millipore) or rabbit IgG control antibodies (Active Motif). Bound and unbound sheared cross-linked chromatin was subsequently eluted according to the manufacturer's instructions. For identification of the CpG-rich Gad67 (from -840 bp to -768 bp) promoter, the following primers were used: 5'-GAGGAGAGCGGGCCAAGA-3' (forward) and $5^{\prime}$-GTGCCGCTCCACACGCC-3' (reverse) (Matrisciano et al., 2013).

Bisulfite sequencing. To determine the methylation pattern of the Gad67 gene promoter, bisulfite sequencing was performed as previously reported (Chew et al., 2012). Briefly, genomic DNA was extracted using the DNeasy Blood and Tissue kit (QIAGEN). Sodium bisulfite treatment of genomic DNA was performed using an EpiTect Bisulfite kit (QIAGEN), according to the manufacturer's protocol. Following bisulfite treatment, the promoter region of the Gad67 gene was amplified by PCR using the following primers: $5^{\prime}$-CGTTTAGTAATGTGTTTAAATAT TG-3' (forward) and 5'-GAACACAACTACCTAACACCACAAA-3' (reverse). The PCR products were cloned into the pT7 blue vector (Novagen), and at least 8 randomly selected clones were sequenced using the T7 and M13 universal primers.

Measurement of SAM concentration. For measurement of SAM, a commercial ELISA kit (STA-671-C, Cell Biolabs) was used according to the manufacturer's instructions. Briefly, all samples were extracted using cold PBS and centrifuged at $10,000 \times g$ for $15 \mathrm{~min}$ at $4^{\circ} \mathrm{C}$. The supernatant was collected and used for SAM measurement, and the insoluble pellet was suspended in lysis buffer. Protein concentrations were measured using the BCA Protein Assay Kit (Thermo Fisher Scientific). For ELISA measurement, the sample volume was normalized using $100 \mu \mathrm{g}$ of protein.

Behavioral analysis and methionine (MET) administration schedule. Mice were treated with saline or MET $(5.2 \mathrm{mmol} / \mathrm{kg}$, s.c.) twice per day from day 0 to day 5 ( $6 \mathrm{~d}$ ). To evaluate changes in spontaneous, cognitive, and anxious behaviors after $6 \mathrm{~d}$ of MET treatment, all mice were subjected to the open field test (OFT), hole-board test (HBT), and novel object recognition test (NORT). The experimenters were blinded to the genotype and scored mouse behaviors throughout the analyses. During the behavioral testing period (7-9 d), the mice received saline or MET $(5.2 \mathrm{mmol} / \mathrm{kg}$, s.c.) once per day. All behaviors were automatically monitored with a CompACT VAS/DV video-tracking system (Muromachi 
Kikai). During all behavioral tests, the total moving distance, total moving time, and velocity were monitored for each group of mice.

The OFT has been used to examine locomotor activity in a novel environment and anxiety (Archer, 1973). The open field arena $(40 \mathrm{~cm} \times$ $40 \mathrm{~cm} \times 30 \mathrm{~cm}$ ) was divided into 36 squares to indicate the position of the mice. The mice were initially placed in the center of the open field arena, and their behavior was monitored for $5 \mathrm{~min}$. The elapsed time and ambulation in the board area (number of outer squares entered) and the central area (number of inner squares entered) were recorded.

The HBT has been used to examine novelty-seeking behavior and anxiety (File and Wardill, 1975). The mice were placed in a gray acrylic arena $(40 \mathrm{~cm} \times 40 \mathrm{~cm} \times 30 \mathrm{~cm}$ ) with four equidistant floor holes $3 \mathrm{~cm}$ in diameter, and the hole-poke activity was scored. The total elapsed time spent in the center, total number of head-dips, head-dip duration, and latency to the first head-dip during the $5 \mathrm{~min}$ testing period were recorded.

The NORT, based on the tendency of rodents to discriminate a familiar object from a new object, was used to evaluate cognitive function (Ennaceur et al., 1997). During the acquisition phase, four objects of the same material were placed diagonally in the corners of the chamber for 10 min. One hour after the acquisition-phase training, two objects were replaced with novel objects, and the exploratory behavior was again analyzed for $5 \mathrm{~min}$. After each phase, the objects were thoroughly cleaned with $75 \%$ ethanol to prevent odor recognition. Exploration of an object was defined as rearing on the object or sniffing it at a distance of $<1 \mathrm{~cm}$, touching it with the nose, or both behaviors. Successful recognition of a previously explored object was reflected by preferential exploration of the novel object. Discrimination of spatial novelty was assessed by comparing the difference between the time of exploration of the novel (right) and familiar (left) objects and the total time spent exploring both objects.

Experimental design and statistical analysis. All values are expressed as the mean \pm SEM. Comparisons between two experimental groups (WT vs Fabp3 KO mice) were performed using unpaired Student's $t$ tests. MET treatment analyses and behavioral tests were analyzed using twoway ANOVA, followed by one-way ANOVA for each group and Dunnett's tests. A $p$ value $<0.05$ was considered significant.

\section{Results}

\section{FABP3 is highly expressed in $\mathrm{PV}^{+}$GABAergic interneurons of the ACC}

Our previous studies showed that FABP3 is expressed in the mouse cerebral cortex (Shioda et al., 2010, 2014); however, FABP3-immunopositive $\left(\mathrm{FABP}^{+}\right)$cells have not been identified to date. According to RT-PCR and qPCR of various brain regions, Fabp 3 was highly expressed in the ACC (Fig. $1 A ; t_{(10)}=$ $3.861, p<0.0001$ for mPFC; $t_{(10)}=9.780, p<0.0001$ for striatum; $t_{(10)}=6.032, p<0.0001$ for AM, unpaired $t$ test vs ACC). Based on immunohistochemistry experiments, $\mathrm{FABP}^{+}$cells were scattered throughout layers II-VI (Fig. $1 B-F$ ) and were negative for the pyramidal cell marker neurogranin (Fig. 1B). Most $\mathrm{FABP}^{+}$neurons were positive for $\mathrm{PV}^{+}$, an inhibitory neuron marker, whereas $\mathrm{FABP} 3$ was barely detectable in $\mathrm{SOM}^{+}$or $\mathrm{CR}^{+}$ neurons in the ACC (Fig. 1C-E; Table 1). Moreover, FABP3 was localized to Gad67 promoter-driven $\mathrm{GFP}^{+}$neurons (Fig. $1 F$ ). These results confirm that $\mathrm{FABP} 3$ is specifically expressed in $\mathrm{PV}^{+}$ inhibitory GABAergic interneurons in the ACC.

\section{Fabp3 gene ablation upregulates GAD67 protein and mRNA expression in the ACC}

To investigate whether the lack of FABP3 could lead to abnormalities in GABAergic inhibitory interneurons, we examined the number of $\mathrm{PV}^{+}, \mathrm{SOM}^{+}$, and $\mathrm{CR}^{+}$neurons in the ACC of Fabp3 $\mathrm{KO}$ mice. There were no significant differences in neuron numbers between WT and Fabp 3 KO mice (Fig. $2 A ; t_{(6)}=0.3288$, $p=$ 0.7434 for PV; $t_{(10)}=0.3169, p=0.7532$ for SOM; $t_{(10)}=0.0325$, $p=0.9742$ for CR, unpaired $t$ test vs WT). The expression of inhibitory synaptic proteins (GAD67, GAD65, VGAT, GABA ${ }_{\mathrm{A}} \mathrm{R}$, and gephyrin) in the ACC was subsequently examined by Western blotting analysis. Notably, levels of GAD67, a rate-limiting enzyme in basal GABA synthesis (Asada et al., 1997), were increased in the ACC of Fabp $3 \mathrm{KO}$ mice compared with those in WT mice, whereas the remaining proteins did not show significant alterations in expression (Fig. $2 B ; t_{(10)}=8.8230, p<0.0001$ for GAD67; $t_{(8)}=1.3607, p=0.2106$ for GAD65; $t_{(8)}=1.9252$, $p=0.0904$ for VGAT; $t_{(8)}=0.3157, p=0.7603$ for $\mathrm{GABA}_{\mathrm{A}} \mathrm{R}$; $t_{(9)}=0.3999, p=0.6985$ for gephyrin, unpaired $t$ test). Consistent with this finding, the expression of Gad67 mRNA (Fig. 2C; $t_{(6)}=4.8293, p<0.0001$, unpaired $t$ test) and concentration of GABA (Fig. $2 D ; t_{(10)}=2.7971, p=0.0189$, unpaired $t$ test) were significantly elevated in the ACC of Fabp3 KO mice, as indicated by qPCR and ELISA, respectively. These changes were not detected in the $\operatorname{mPFC}\left(t_{(6)}=0.2414, p=0.8153\right.$ for GAD67 protein; $t_{(6)}=0.7262, p=0.4748$ for Gad67 mRNA; $t_{(10)}=0.5738, p=$ 0.5788 for GABA, unpaired $t$ test $)$ or $\mathrm{AM}\left(t_{(6)}=0.4361, p=\right.$ 0.6780 for GAD67 protein; $t_{(6)}=0.8160, p=0.4202$ for Gad67 mRNA; $t_{(8)}=0.2470, p=0.8111$ for GABA, unpaired $t$ test) of Fabp3 KO mice (Fig. $2 E-G$ ). Moreover, amounts of DA $\left(t_{(9)}=\right.$ $0.0927, p=0.9282$, unpaired $t$ test $)$ and $5-\mathrm{HT}\left(t_{(10)}=0.2092, p=\right.$ 0.8385 , unpaired $t$ test) did not exhibit differences between WT and Fabp3 $\mathrm{KO}$ mice (Fig. 2 H,I). Together, these results suggest that Fabp3 ablation in GABAergic interneurons specifically increases GAD67 expression, which consequently enhances inhibitory synaptic transmission in the ACC.

We subsequently examined whether Fabp3 expression levels are negatively correlated with Gad67 expression levels in differentiated neuroblastoma Neuro-2A cells, in which Gad67 is expressed (Manabe et al., 2005; Sato and Shibuya, 2013). In differentiated Neuro-2A cells, the overexpression of Fabp 3 significantly decreased Gad67 expression levels (Fig. 2J; $t_{(6)}=4.2862$, $p=0.0003$, unpaired $t$ test). In contrast, siRNA knockdown of Fabp3 significantly increased Gad67 expression levels (Fig. 2J; $t_{(6)}=3.0821, p=0.0054$, unpaired $t$ test). These data suggest that FABP3 may negatively modulate Gad67 expression in a cellautonomous manner in GABAergic inhibitory neurons.

\section{Enhancement of inhibitory, but not excitatory, synaptic plasticity in Fabp3 KO mice}

To determine whether Fabp3 ablation directly affects inhibitory synaptic transmission in the ACC, we measured $\mathrm{mEPSC} / \mathrm{mIPSC}$ using whole-cell voltage-clamp recordings in layer II/III ACC pyramidal neurons prepared from WT or Fabp3 KO mice after blocking action potential firing with tetrodotoxin. The mEPSC frequency and amplitude were unaffected by $F a b p 3$ ablation (Fig. $3 A-C ; t_{(8)}=1.1385, p=0.2573$ for frequency; $t_{(8)}=0.3570, p=$ 0.7218 for amplitude, unpaired $t$ test). Interestingly, in contrast to the mEPSC, the mIPSC frequency was significantly increased in Fabp3 $\mathrm{KO}$ mice compared with that in WT mice (Fig. $3 A, B$; $t_{(8)}=10.5217, p<0.0001$, unpaired $t$ test) without a change in amplitude (Fig. $3 A, C ; t_{(8)}=1.1242, p=0.2634$, unpaired $t$ test); these findings suggest that the loss of FABP 3 resulted in a surplus of inhibitory presynaptic transmission. Sequential recordings of the mEPSC and mIPSC from the same ACC pyramidal neuron indicated different responses in WT and KO mice: there was a significant correlation between the MEPSC and MIPSC frequencies of individual pyramidal neurons from Fabp $3 \mathrm{KO}$ but not WT mice (Fig. 3B). Collectively, pyramidal neurons in the ACC of Fabp3 KO mice received greater inhibitory synaptic input than those of WT mice. Thus, FABP3 may balance the excitatory and 
A

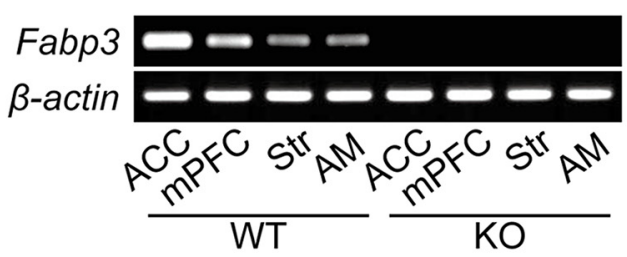

B
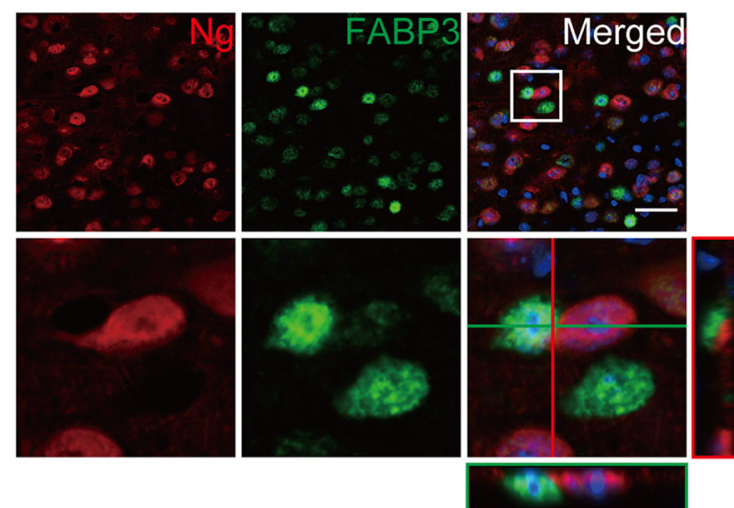

C
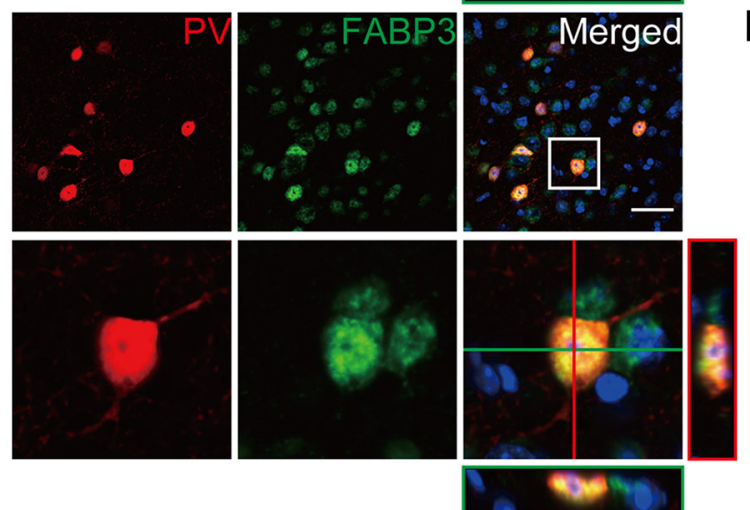

$\mathbf{F}$
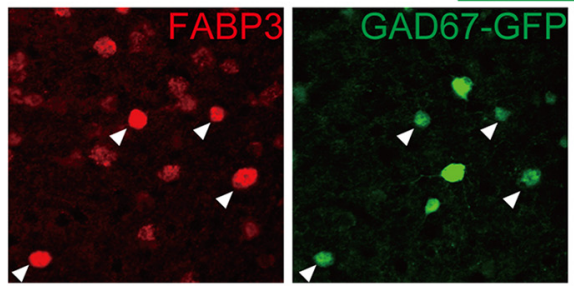

Figure 1. FABP3 was strongly expressed in $P V{ }^{+} G A B A e r g i c$ interneurons of the $A C C . A$, Left, RT-PCR analysis of Fabp 3 in different brain areas. Right, $q P C R$ analysis of Fabp 3 in different brain areas. Error bar indicates mean \pm SEM. $n=6$ mice per group. ${ }^{* *} p<0.01$ versus WT ACC. $\boldsymbol{B}-\boldsymbol{F}$, Confocal images showing colocalization of FABP3 and a pyramidal neuronal marker (Ng), three classical GABAergic neuronal makers (PV, SOM, and CR), or GAD67 in the ACC. $B$, Most FABP3 ${ }^{+}$structures do not show immunoreactivity for Ng. C, Confocal images showing FABP3 and PV colocalization in the ACC. D, $\boldsymbol{F}$, Most FABP ${ }^{+}$structures do not show immunoreactivity for SOM (D) or CR (E). F, Confocal images showing FABP3 and GAD67 colocalization in the ACC (arrowheads). B, C (bottom), $\boldsymbol{D}$, $\boldsymbol{E}$ (bottom right), $\boldsymbol{F}$ (right), Enlarged images of the boxed area in the merged image. Scale bars, $50 \mu \mathrm{m}$. Str, Striatum.

Table 1. Colocalization of PV, SOM, and CR with FABP3 in the ACC

\begin{tabular}{|c|c|c|c|}
\hline & PV & SOM & $C R$ \\
\hline $\begin{array}{l}\text { FABP3 }{ }^{-} \text {cell number } \\
\text { (per } 160 \mathrm{~mm}^{2} \text { ) }\end{array}$ & $2.3 \pm 0.20$ & $11.1 \pm 0.72$ & $12.4 \pm 0.50$ \\
\hline $\begin{array}{l}\mathrm{FABP}^{+} \text {cell number } \\
\quad\left(\text { per } 160 \mathrm{~mm}^{2} \text { ) }\right.\end{array}$ & $9.5 \pm 0.60$ & $1.2 \pm 0.17$ & 0 \\
\hline $\begin{array}{l}\text { Total cell number } \\
\quad\left(\text { per } 160 \mathrm{~mm}^{2} \text { ) }\right.\end{array}$ & $11.7 \pm 0.71$ & $12.3 \pm 0.75$ & $12.4 \pm 0.50$ \\
\hline$\%$ of FABP3 ${ }^{+}$ & $80.6 \pm 1.42$ & $10.3 \pm 1.98$ & 0 \\
\hline
\end{tabular}

${ }^{a}$ Data are mean \pm SEM.
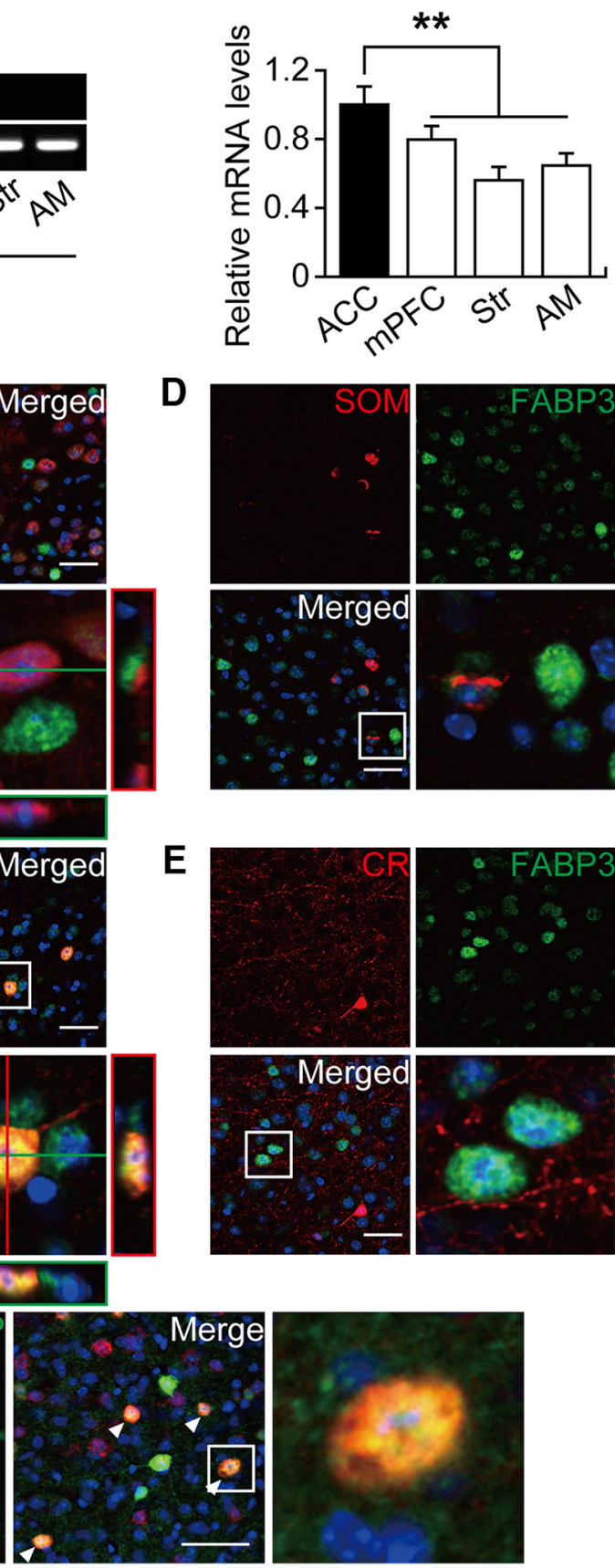

E

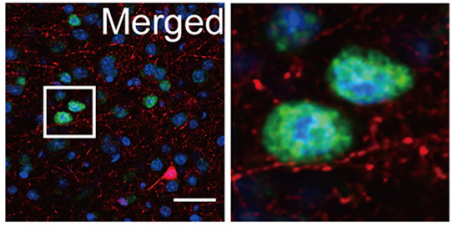

inhibitory inputs to pyramidal neurons through the regulation of GABA synthesis.

Altered glutamatergic transmission in the ACC of Fabp3 KO mice and expression of glutamatergic synaptic vesicle proteins

We previously demonstrated that Fabp3 KO mice exhibit dopamine $\mathrm{D}_{2}$ receptor dysfunction and increased glutamate release in the dorsal striatum (Shioda et al., 2010). However, in general, GABA negatively regulates glutamate release through the $\mathrm{GABA}_{\mathrm{B}}$ receptor (Bonanna et al., 1997; Isaacson and Hille, 1997; Li et al., 
A
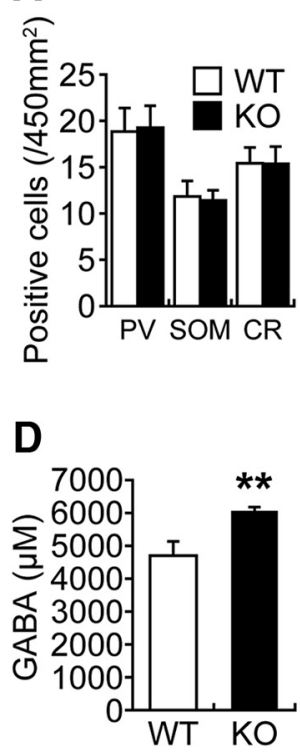

B

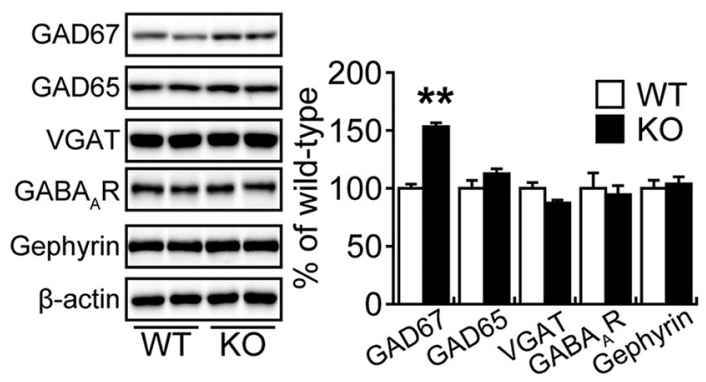

E
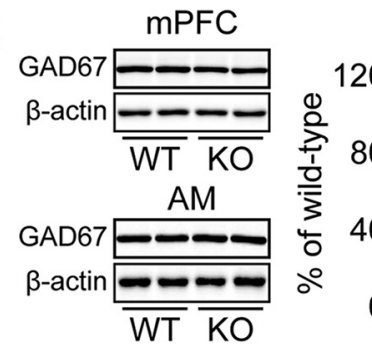

C
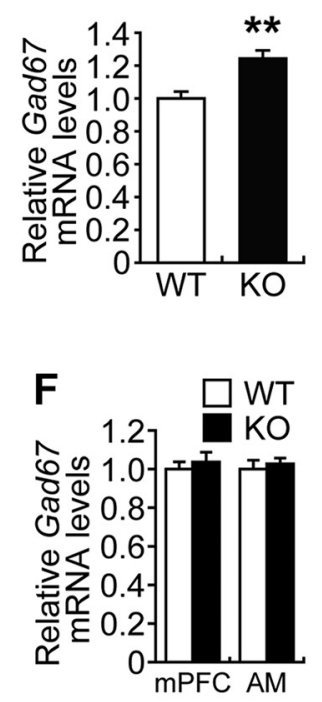

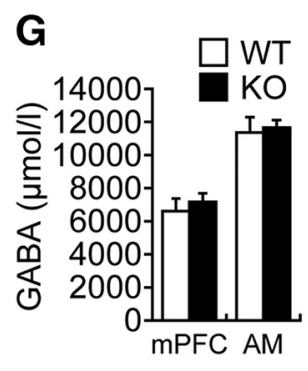

H

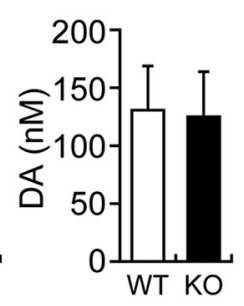

I

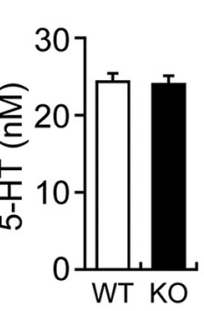

J

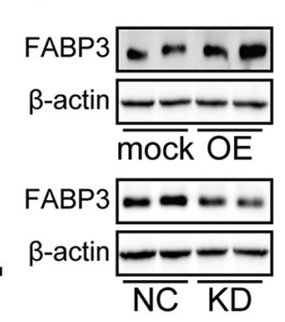

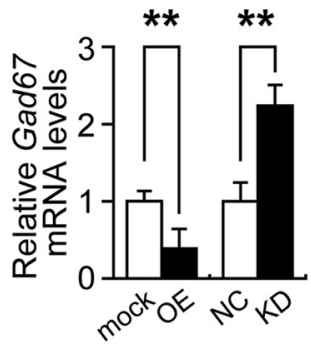

Figure 2. Fabp3 gene ablation in the ACC caused upregulation of GAD67 expression and GABA synthesis. $A$, Quantitative analysis of the number of $\mathrm{PV}^{-}, \mathrm{SOM}^{-}$, and $\mathrm{CR}^{+}$neurons in the $\mathrm{ACC}$. PV, $n=8$ sections, 4 mice; SOM, $n=12$ sections, 6 mice; $C R, n=12$ sections, 6 mice per group. $\boldsymbol{B}$, Representative immunoblots (left) and quantitative densitometry analysis (right) probed with GABA-related antibodies. GAD67 and $\beta$-actin, $n=6$ mice per group; GAD65, VGAT, and GABA $A_{A} R=5$ mice per group; gephyrin, $n=5$ and 6 WT and Fabp 3 K0 mice, respectively. C, Quantitative analysis of Gad67 mRNA expression in the ACC from WT and Fabp3 KO mice. $n=4$ mice per group. D, Quantitative analysis of the GABA concentrations in ACC extracts from WT and Fabp3 K0 mice by ELISA. $n=6$ mice per group. $E-G$, There were no differences in GAD67 expression or GABA synthesis in the mPFC or AM of Fabp 3 K0 mice. $E$, Representative immunoblots (left) and quantitative densitometry analysis (right) probed with GAD67 antibody. $n=4$ mice per group. $F$, Quantitative analysis of the Gad67 mRNA expression. $n=4$ mice per group. G, Quantitative analysis of the GABA concentrations in the mPFC and AM extracts by ELISA. mPFC, $n=6$ mice per group; AM, $n=4$ and 6 WT and Fabp 3 KO mice, respectively. $H$, I, Quantitative analysis of the DA and 5 -HT concentrations in ACC extracts by ELISA. 5 -HT, $n=6$ mice per group; DA, $n=6$ and 5 WT and Fabp 3 KO mice, respectively. $A-I,{ }^{* *} p<0.01$ versus WT mice.J, Left, Representative immunoblots probed with FABP3 antibody. Right, Quantitative analysis of Gad67 mRNA in Neuro-2a cells. $n=4$ per group. ${ }^{* *} p<0.01$ versus control. mock, Mock control; $0 \mathrm{E}$, Fabp3 overexpression; NC, negative control; KD, Fabp3 knockdown. Error bar indicates mean \pm SEM.

2002; Rost et al., 2011; Higley, 2014); thus, it is possible that glutamate release is reduced in the ACC of Fabp3 KO mice. To confirm this hypothesis, we measured basal and depolarizationinduced glutamate release in freely moving mice. As expected, the basal glutamate release was significantly decreased in the ACC of Fabp3 KO mice compared with that in WT mice (Fig. 4A, left). Area under the curve (AUC) analysis also showed that the basaland high $\mathrm{KCl}$-evoked glutamate release was significantly decreased in Fabp3 $\mathrm{KO}$ mice (Fig. $4 \mathrm{~A}$, right; $t_{(9)}=2.9984, p=$ 0.0171 for basal; $t_{(9)}=2.8990, p=0.0199$ for high $\mathrm{K}^{+}$, unpaired $t$ test). In addition, the responsiveness of glutamate release to depolarization stimulation was not altered in Fabp3 KO mice (Fig. $4 B ; t_{(9)}=1.3113, p=0.2261$, unpaired $t$ test). Consistent with these findings, the phosphorylation of CaMKIV and CREB and the expression of BDNF, which are indicative of glutamatergic signal transduction, were markedly decreased in the ACC of Fabp3 KO mice (Fig. $4 C ; t_{(10)}=2.0980, p=0.040$ for pCaMKIV; $t_{(10)}=2.3883, p=0.0381$ for $\mathrm{pCREB} ; t_{(10)}=2.3993, p=0.0374$ for BDNF, unpaired $t$ test). To further investigate the effect of Fabp3 gene ablation on the synaptic profile, we examined the expression of synaptic proteins (synaptophysin, VGLUT1, and PSD95) in the ACC. Significant increases in the expression of synaptophysin, a general marker for presynaptic vesicle membranes, and VGLUT1, a marker for the glutamatergic presynaptic vesicle, were observed, whereas the expression of PSD95, an excitatory postsynaptic scaffold protein, was not altered (Fig. $4 D$; $t_{(10)}=5.7168, p=0.0002$ for synaptophysin; $t_{(10)}=7.8830, p=$ 0.00001 for VGLUT1; $t_{(10)}=0.6290, p=0.5435$ for PSD95, unpaired $t$ test).

\section{Decreased binding of MeCP2 and HDAC1 to the Gad67 promoter region in the ACC of Fabp3 KO mice}

It has been reported that the inhibition of DNMT1 or HDAC1 increases Gad67 expression (Kundakovic et al., 2007, 2009), which indicates that the DNA methylation and assembly of repressor complexes containing HDAC1 are important for silencing of the Gad67 promoter. To explore whether the upregulation of Gad67 expression in the ACC of Fabp3 KO mice is associated with Gad67 promoter silencing, the binding of MeCP2 and HDAC1 to specific Gad67 CpG-rich promoter sequences ( -154 

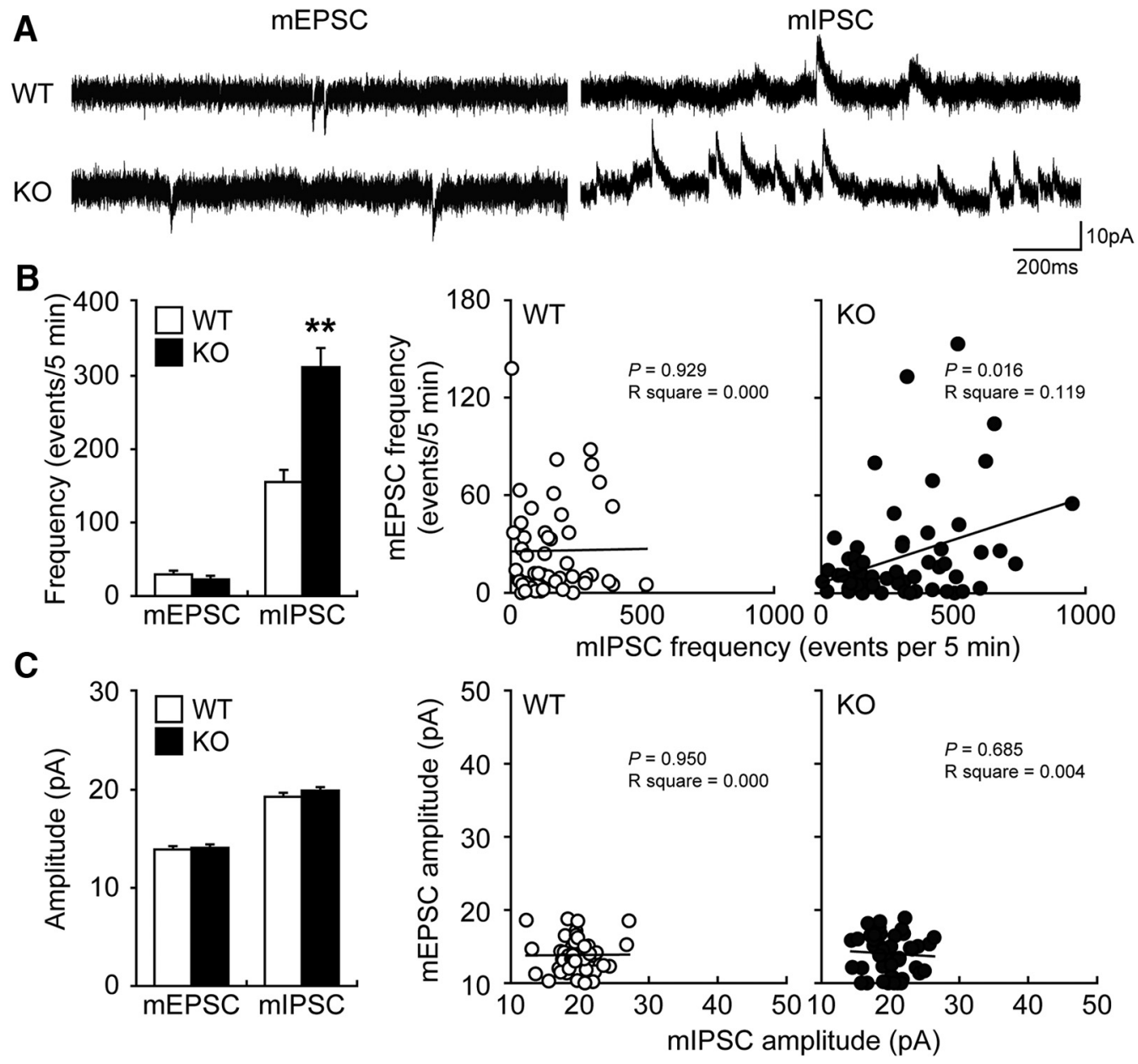

Figure 3. Enhancement of inhibitory synaptic plasticity in the ACC of Fabp $3 \mathrm{KO}$ mice. $A$, Representative traces of $\mathrm{mEPSCs}$ and mIPSCs in ACC layer II/III pyramidal neurons. $\boldsymbol{B}$, Plots of the $\mathrm{mEPSC}$ and mIPSC frequencies in WT and Fabp3 KO mice. C, Plots of the mEPSC and mIPSC amplitudes in WT and Fabp3 KO mice. $n=53$ cells for WT and 59 cells for Fabp 3 KO from 5 mice for mEPSCs. $n=$ 52 cells for WT and 60 cells for Fabp 3 KO from 5 mice for mIPSCs. ${ }^{* *} p<0.01$ versus WT mice. Error bar indicates mean \pm SEM.

to 21) was examined via ChIP assay. We first confirmed that the expression of MeCP2 and HDAC1 in the ACC was not affected by Fabp3 deficiency (Fig. $5 A ; t_{(10)}=0.4912, p=0.6407$ for MeCP2; $t_{(10)}=1.3455, p=0.2271$ for HDAC1, unpaired $t$ test); interestingly, the binding of MeCP2 and HDAC1 to the Gad67 promoter region was significantly decreased in the ACC of Fabp3 KO mice (Fig. $5 B ; t_{(7)}=3.9027, p=0.0059$ for MeCP2; $t_{(7)}=4.2154, p=$ 0.0040 for HDAC1, unpaired $t$ test).

Chronic MET treatment has previously been reported to downregulate GAD67 expression in the mouse frontal cortex by increasing methylation of the Gad67 promoter and recruiting MeCP2 to the Gad67 promoter (Dong et al., 2005, 2007). Therefore, we assessed the effect of methyl donor treatment on the methylation status of the Gad67 CpG-rich promoter region and the expression of Gad67 mRNA in the Fabp3 KO ACC. We determined that the number of methylated cytosine residues at $\mathrm{CpG}$ sites in the Gad67 promoter was decreased in the ACC of Fabp3 KO mice but was increased after MET treatment for $9 \mathrm{~d}$ (Fig. 5C). Consistent with these changes in Gad67 promoter methylation, MET treatment of Fabp3 KO mice restored Gad67 expression in the ACC to levels comparable with that in vehicle-treated WT mice (Fig. 5D; WT: KO, $t_{(9)}=4.8293, p=0.0003$; $\mathrm{KO}: \mathrm{KO}+$ MET, $t_{(9)}=2.9163, p=0.0068$, unpaired $t$ test). We then measured levels of SAM, which is biosynthesized from MET and acts as a direct methyl donor (Szyf, 2015). However, there were no significant differences in SAM levels in the ACC between WT and Fabp3 KO mice (Fig. $5 E ; t_{(6)}=1.8038, p=0.1043$, unpaired $t$ test). In contrast, in differentiated Neuro-2A cells, the overexpression of Fabp3 significantly increased intracellular SAM levels (Fig. $5 F ; t_{(6)}=3.4647, p=0.0033$, unpaired $t$ test).

Amelioration of behavioral abnormalities in Fabp3 $\mathrm{KO}$ mice by chronic MET treatment

As perturbation of the excitatory/inhibitory balance in the ACC leads to behavioral abnormalities, Fabp3 $\mathrm{KO}$ mice were treated with MET and submitted to a behavioral testing battery to evaluate emotional and cognitive functions (Fig. 6A). Based on the OFT, performed to evaluate locomotor activity and anxiety (Archer, 1973), there were no differences in locomotor activity or the time spent in the center area between Fabp3 KO and WT mice (Fig. $6 B ; t_{(32)}=0.3261, p=0.7464$, unpaired $t$ test). The results of the HBT, performed to evaluate novelty-seeking behavior and anxiety (File and Wardill, 1975), showed that Fabp3 KO mice spent less time in the center area of the open field and exhibited significantly less head-dipping into the hole than WT mice (Fig. $6 C ; t_{(25)}=4.0959, p=0.0004$ for total center time; $t_{(27)}=3.7165$, $p=0.0009$ for head-dip count; $t_{(27)}=2.8561, p=0.0082$ for head-dip duration; $t_{(27)}=3.7443, p=0.0009$ for head-dip latency, unpaired $t$ test). Based on the results of the NORT, performed to evaluate cognitive function (Ennaceur et al., 1997), the 
A

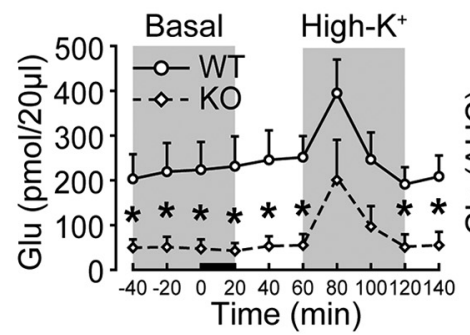

B

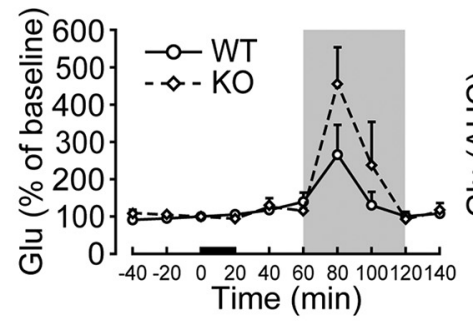

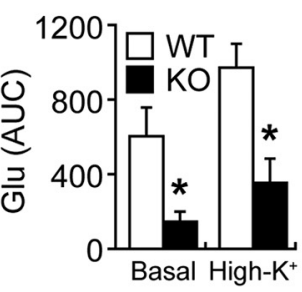

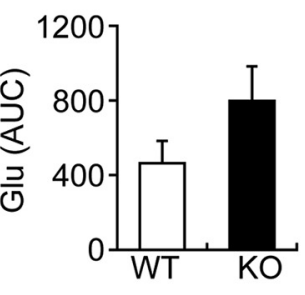

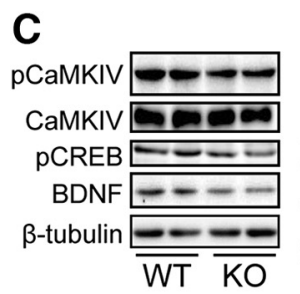
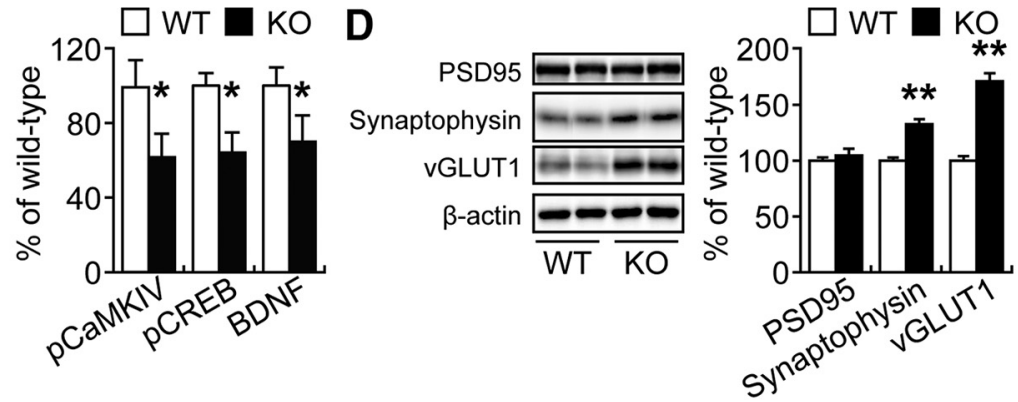

Figure 4. Extracellular glutamate (Glu) concentrations in the ACC in freely moving animals. $A$, Dialysate Glu concentrations at baseline (basal) and after depolarization stimulation (High- ${ }^{+}$) (left). Glu AUC before (basal) and after (High-K ${ }^{+}$) depolarization stimulation (right). ${ }^{*} p<0.05$ versus wild-type mice. $\boldsymbol{B}$, Normalization of the dialysate Glu signals indicated that the response to depolarization stimulation was enhanced in Fabp3 $\mathrm{KO}$ mice (left). The normalized Glu AUC after depolarization stimulation (right). $A, B$, Error bar indicates mean \pm SEM. ${ }^{*} p<0.05$ versus WT mice. $n=6$ WT mice; $n=5$ Fabp3 K0 mice. C, $\boldsymbol{D}$, Representative immunoblots (left) and quantitative densitometry analysis (right) probed with various antibodies. ${ }^{*} p<0.05$; ${ }^{* *} p<0.01$ versus WT mice. $n=6$ mice per group. Error bar indicates mean \pm SEM.

discrimination index did not differ between WT and Fabp3 KO mice in the trial session, but Fabp $3 \mathrm{KO}$ mice failed to discriminate a novel object from a familiar object in the test session (Fig. $6 D$; $t_{(26)}=8.4820, p<0.0001$ for WT; $t_{(26)}=0.9327, p=0.3595$ for Fabp3 KO, unpaired $t$ test). These results, which are mostly consistent with our previous findings (Shimamoto et al., 2014; Yabuki et al., 2018), indicate that Fabp3 KO mice show altered cognitive and emotional behaviors.

Finally, we examined whether chronic MET treatment improves the behavioral deficits exhibited by Fabp $3 \mathrm{KO}$ mice. In the OFT, there were no differences in time spent in the center area among the groups following MET treatment (Fig. 6B; WT: WT + MET, $t_{(29)}=0.3668, p=0.7164 ; \mathrm{KO}: \mathrm{KO}+\mathrm{MET}, t_{(31)}=0.5350$, $p=0.5965$, unpaired $t$ test). Moreover, chronic MET treatment of Fabp3 KO mice significantly improved their impaired explorative behaviors in the HBT (KO: KO + MET, $t_{(24)}=4.3079, p=$ 0.0002 for total center time; $t_{(25)}=4.4016, p=0.0002$ for headdip count; $t_{(25)}=4.0482, p=0.0004$ for head-dip duration; $t_{(25)}=3.4921, p=0.0018$ for head-dip latency, unpaired $t$ test), whereas the behavior of WT mice was not affected by MET treatment $\left(\mathrm{WT}\right.$ : WT + MET, $t_{(25)}=1.8068, p=0.0829$ for total center time; $t_{(26)}=0.3319, p=0.7426$ for head-dip count; $t_{(26)}=$ $0.3178, p=0.7532$ for head-dip duration; $t_{(26)}=0.4144, p=$ 0.6820 for head-dip latency, unpaired $t$ test) (Fig. 6C). Last, chronic MET treatment of Fabp3 KO mice significantly improved the impaired discrimination index during the test session (KO: KO + MET, $t_{(20)}=4.570, p=0.0002$, unpaired $t$ test), whereas the behavior of WT mice was not affected by MET treat- ment (WT: WT + MET, $t_{(20)}=5.7670, p=0.00001$, unpaired $t$ test) (Fig. 6D). There was no significant difference in locomotor activity among the groups during the test (Table 2).

\section{Discussion}

In the present study, we identified $\mathrm{FABP} 3$ as a negative regulator of Gad67 mRNA expression in GABAergic interneurons of the ACC. First, we found that FABP3 was exclusively expressed in $\mathrm{PV}^{+}$GABAergic inhibitory interneurons in the ACC. Second, increased GAD67 expression, GABA levels, and mIPSC frequency were detected in the ACC of Fabp3 KO mice. Third, the Gad67 promoter was hypomethylated, and the binding of transcriptional repressor complexes to the Gad67 promoter was decreased in the ACC of Fabp3 KO mice. Finally, normal Gad67 mRNA expression levels and behaviors exhibited by Fabp3 KO mice were mostly restored by MET treatment. Based on these observations, we suggest that FABP3 regulates GABA synthesis in GABAergic inhibitory interneurons through transcriptional regulation of Gad67 in the ACC.

FABP3 was specifically expressed in $\mathrm{PV}^{+}$interneurons and not in pyramidal neurons in the ACC. $\mathrm{PV}^{+}, \mathrm{SOM}^{+}$, and $\mathrm{CR}^{+}$ neurons are thought to be constitutively independent neuron groups in the rodent frontal cortex (Hladnik et al., 2014). PV ${ }^{+}$ interneurons are the major players that maintain a proper excitatory/inhibitory balance in the $\mathrm{CNS} \mathrm{PV}^{+}$interneurons constitute $\sim 40 \%$ of GABAergic interneurons in layers II to VI of the frontal cortex, including the ACC (Uematsu et al., 2008), whereas $\mathrm{SOM}^{+}$and $\mathrm{CR}^{+}$interneurons constitute $\sim 20 \%$ and $15 \%$, re- 
A

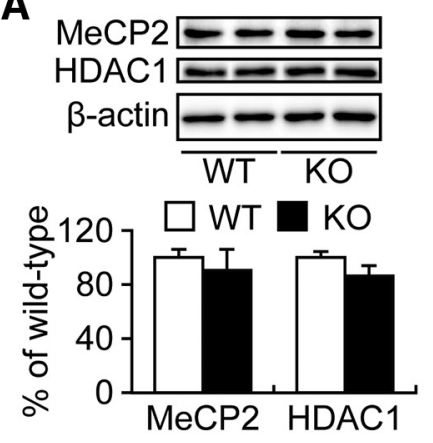

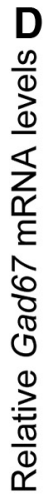

B

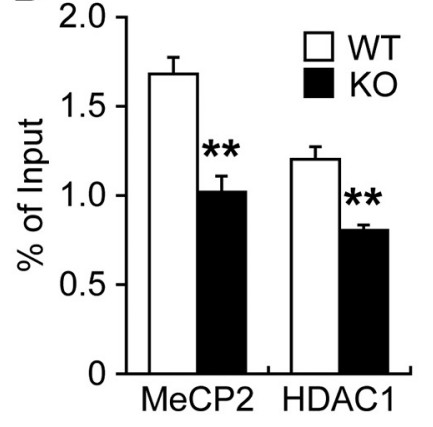

$\mathbf{F}$
C

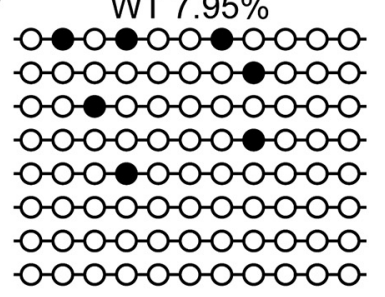

KO $2.27 \%$

-0-0-0-0-0-0-0-

$0-0-0-0-0-0-0-0$

-0-0-0-0-0-0-0-0-0-

- - -0-0-0-0-0-0-0

-0-0-0-0-0-0-0-0-

- - -0-0-0-0-0-0-0

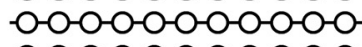

-0-0-0-0-0-0-0

KO+MET 12.5\%

- O-0-0-0-0-0-0

-0-0-0-0-0-0-0-

$0-0-0-0-0-0-0-0-0$

$0-0-0-0-0-0-0-0$

-0-0-0-0-0-0-0-0-

-0-0-0-0-0-0-0-

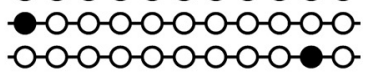

Figure 5. Decreased binding of MeCP2 and HDAC1 to the Gad67 promoter region in the ACC of Fabp3 KO mice. A, Representative immunoblots (top) and quantitative densitometry analysis (bottom) probed with various antibodies are shown. $n=6$ mice per group. $B$, ChIP assay of ACC extracts from WT or Fabp 3 KO mice via anti-MeCP2 and HDAC1. The precipitated DNA was analyzed by qPCR with primers amplifying the Gad67 promoter region. ${ }^{* *} p<0.01$ versus WT mice. $n=5$ WT mice. $n=4$ Fabp 3 KO mice. C, DNA methylation profile in the Gad 67 promoter region determined by bisulfite sequencing. Black circles represent methylated CpGs. Open circles represent unmethylated sites. Top numbers indicate global percentages of methylated cytosines. $\boldsymbol{D}$, Quantitative analysis of the Gad67 mRNA expression in the ACC. WT, $n=6 ; \mathrm{KO}, n=5 ; \mathrm{KO}+\mathrm{MET}, n=6$ mice per group. ${ }^{* *} p<0.01$ versus WT mice. ${ }^{\# \#} p<0.01$ versus KO mice. E, F, Quantitative analysis of the SAM concentration by ELISA. $n=4$ per group. ${ }^{* *} p<0.01$ versus mock control. MET treatment $(5.2 \mathrm{mmol} / \mathrm{kg}$, s.c., twice per day for $6 \mathrm{~d})$. mock, Mock control; $0 \mathrm{E}$, Fabp 3 overexpression. Error bar indicates mean \pm SEM.

spectively. In this study, Fabp 3 ablation did not affect the number of $\mathrm{PV}^{+}, \mathrm{SOM}^{+}$, or $\mathrm{CR}^{+}$interneurons; thus, it is reasonable to assume that the subpopulation of GABA interneurons did not change in Fabp3 KO mice. Based on our present finding that Fabp3 ablation significantly increased the GABA concentration in the ACC, it is reasonable to consider that the GABA synthesis capacity per individual $\mathrm{PV}^{+}$interneuron was increased in the ACC of Fabp3 KO mice.

GABAergic interneurons are distributed throughout the brain and are the main source of neuronal inhibition in the brain, thus playing a key role in controlling and orchestrating the activity of excitatory pyramidal neurons. Enhanced GABAergic inhibition at the glutamatergic terminal via the $G_{A B A}$ receptor results in an overall decrease in the basal and depolarizationinduced release of glutamate. In general, GABA receptors are classified as ionotropic $\mathrm{GABA}_{\mathrm{A}}$ receptors and metabotropic $G_{A B A}$ receptors. Postsynaptic $G_{A B A}$ receptor activation inhibits calcium influx at the postsynaptic membrane via VGCCs and the NMDA receptor (Gassmann and Bettler, 2012), consequently silencing the CaMKIV/CREB/BDNF pathway in excitatory pyramidal neurons. In this study, we demonstrated the hypoactivation of pyramidal neurons in the Fabp3 KO ACC, as indicated by an increase in mIPSC frequency and decrease in basal glutamate release.

Furthermore, the CaMKIV/CREB/BDNF pathway, which is a well-established indicator of neuronal plasticity, was downregulated in the Fabp3 KO ACC. Thus, increased activation of postsynaptic $\mathrm{GABA}_{\mathrm{B}}$ receptors may represent a major cause of the decrease in CaMKIV/CREB/BDNF pathway activity observed in the ACC of Fabp3 KO mice. By contrast, activation of presynaptic $\mathrm{GABA}_{\mathrm{B}}$ receptors inhibits VGCCs, thereby suppressing evoked calcium-dependent neurotransmitter release by inhibiting vesicle fusion to the presynaptic membrane (Gassmann and Bettler, 2012). Thus, the hyperactivation of presynaptic $\mathrm{GABA}_{\mathrm{B}}$ receptor may lead to a decrease in spontaneous glutamate release and the accumulation of synaptic vesicles in the Fabp3 KO ACC. Therefore, this hyperactivation may cause the increase in synaptic vesicle proteins (synaptophysin and VGLUT1) observed in the ACC of Fabp3 KO mice.

Glutamatergic hypoactivity and hyperactivity in the ACC have been associated with various behavioral alterations in humans and animal models. fMRI studies have shown that changes in neuronal activity in the ACC are apparent in patients with obsessive-compulsive disorder with disturbances in motivation (Bush et al., 2002; Szechtman and Woody, 2004; Fitzgerald et al., 2005). In animal studies, it has been shown that the ACC is closely involved in novel object recognition during a task (Weible et al., 2009, 2012). Specifically, the microinfusion of muscimol, a $\mathrm{GABA}_{\mathrm{A}}$ receptor agonist, into the ACC immediately before the retrieval phase decreases exploratory behavior toward novel objects (Pezze et al., 2017). In our present and previous studies, Fabp3 KO mice exhibited decreased performance in noveltyseeking (Shimamoto et al., 2014; Yabuki et al., 2018). Therefore, we suggest that glutamatergic hypoactivity due to FABP3 deficiency in the ACC underlies the decreased novelty-seeking performance in Fabp $3 \mathrm{KO}$ mice. 
A

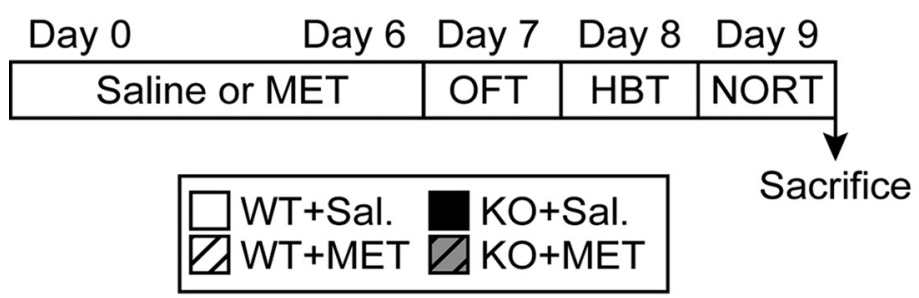

C
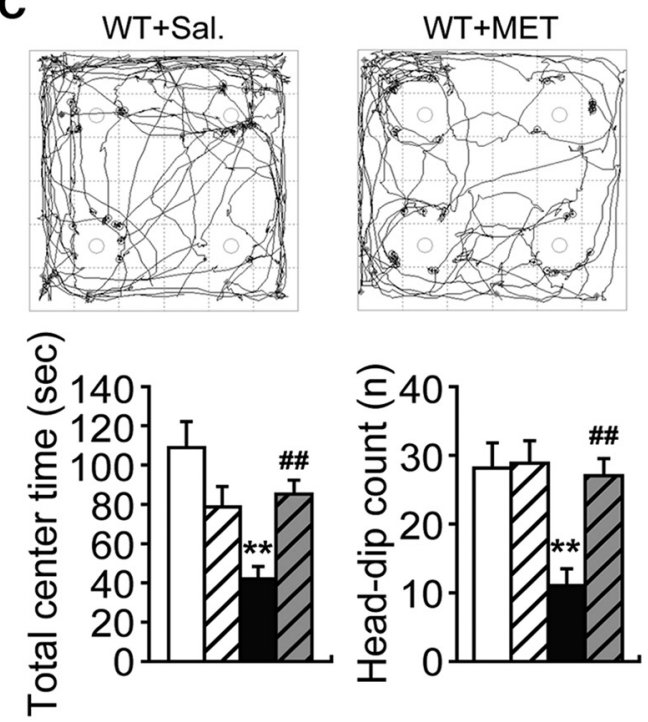

D $\frac{0}{0}$

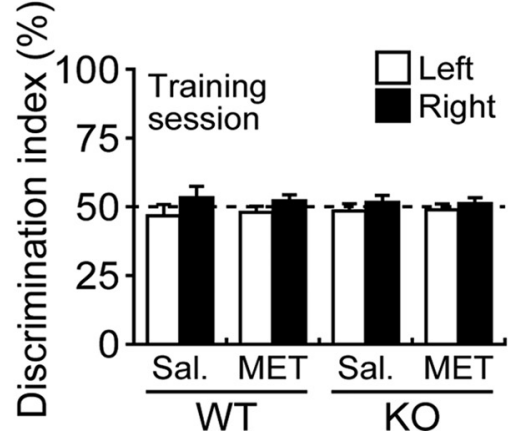

B

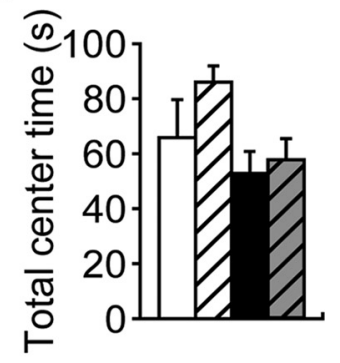

KO+Sal.
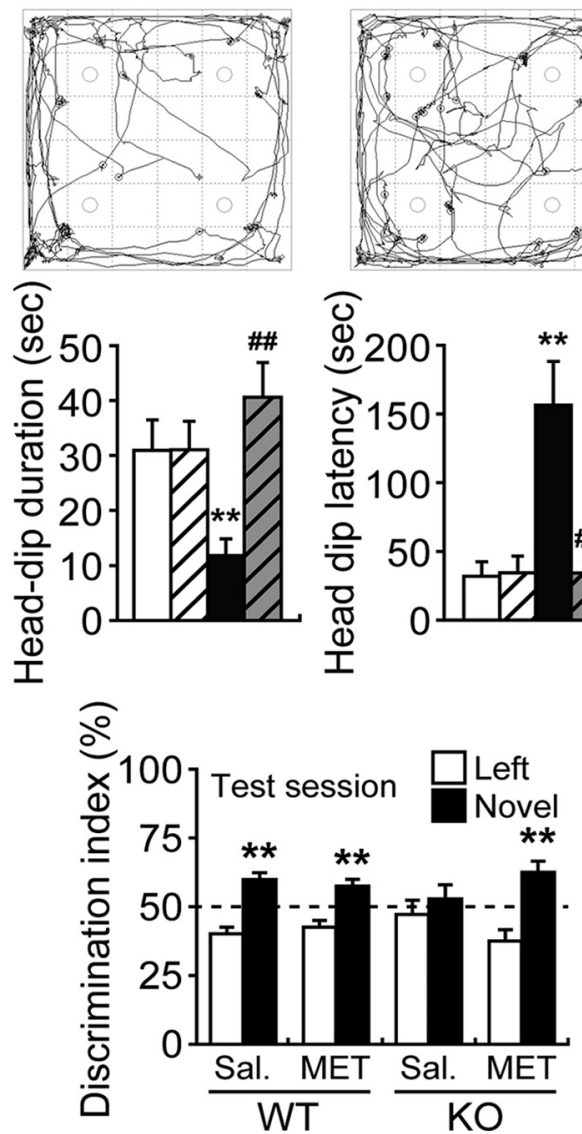

Figure 6. Amelioration of behavioral abnormalities in Fabp3 $\mathrm{KO}$ mice by chronic treatment with MET. $A$, Schematic of the behavioral tests and MET treatment (5.2 mmol/kg, s.C., twice per day). During the behavioral testing period, mice received saline or MET once per day after testing. $\boldsymbol{B}$, OFT. Graph represents the time spent in the center area over a 5 min period for WT and Fabp $30 \mathrm{mice}$. $n=14-17$ mice per group. C, HBT. An illustrative example of the travel pathway in the HBT using video tracking software (top). Graphs represent the time spent in the center area, total number of head-dips, head-dip duration, and latency to first head-dip for the 5 min testing session (bottom). $n=13-15$ mice per group. ${ }^{* *} p<0.01$ versus saline-treated WT mice. ${ }^{\# \#} p<0.01$ versus saline-treated K0 mice. D, NORT. Differences in exploratory preference were assessed between groups in the training (left) or test (right) sessions. $n=11-15$ mice per group. ${ }^{* *} p<0.01$ versus familiar group. Sal, Saline treatment. MET treatment ( $5.2 \mathrm{mmol} / \mathrm{kg}$, S.c., twice per day for $6 \mathrm{~d})$. Error bar indicates mean \pm SEM.

Table 2. Locomotor activities during behavioral tests ${ }^{a}$

\begin{tabular}{llcccc}
\hline Test & Parameter & WT & WT + MET & Fabp3 K0 & Fabp3 K0 + MET \\
\hline OFT & Total moving distance $(\mathrm{cm})$ & $1557.49 \pm 151.75$ & $1862.39 \pm 154.57$ & $2155.62 \pm 202.84$ & $1820.16 \pm 64.01$ \\
& Total moving time $(\mathrm{s})$ & $85.79 \pm 6.90$ & $100.74 \pm 6.59$ & $107.14 \pm 7.24$ & $102.22 \pm 2.35$ \\
& Velocity $(\mathrm{cm} / \mathrm{s})$ & $17.73 \pm 0.43$ & $18.39 \pm 0.60$ & $19.72 \pm 0.59$ & $17.75 \pm 0.28$ \\
HBT & Total moving distance $(\mathrm{cm})$ & $1465.62 \pm 99.00$ & $1311.54 \pm 103.51$ & $1498.69 \pm 117.63$ & $1373.93 \pm 70.57$ \\
& Total moving time $(\mathrm{s})$ & $75.88 \pm 4.01$ & $70.76 \pm 4.65$ & $77.17 \pm 5.09$ & $73.03 \pm 3.75$ \\
& Velocity $(\mathrm{cm} / \mathrm{s})$ & $19.15 \pm 0.55$ & $18.44 \pm 0.34$ & $19.18 \pm 0.41$ & $18.87 \pm 0.35$ \\
NORT (Training) & Total moving distance (cm) & $2108.58 \pm 240.55$ & $1923.98 \pm 325.78$ & $2918.21 \pm 343.45$ & $2758.50 \pm 253.99$ \\
& Total moving time (s) & $111.72 \pm 11.99$ & $106.28 \pm 17.45$ & $143.62 \pm 13.74$ & $143.53 \pm 10.91$ \\
& Velocity $(\mathrm{cm} / \mathrm{s})$ & $18.67 \pm 0.43$ & $18.08 \pm 0.33$ & $19.67 \pm 0.57$ & $19.01 \pm 0.33$ \\
NORT (Test) & Total moving distance $(\mathrm{cm})$ & $1351.41 \pm 192.25$ & $934.83 \pm 126.64$ & $1271.62 \pm 163.09$ & $923.66 \pm 137.54$ \\
& Total moving time $(\mathrm{s})$ & $71.53 \pm 9.31$ & $52.43 \pm 7.08$ & $69.02 \pm 8.63$ & $48.70 \pm 5.94$ \\
& Velocity $(\mathrm{cm} / \mathrm{s})$ & $18.76 \pm 0.50$ & $17.86 \pm 0.24$ & $18.39 \pm 0.50$ & $18.49 \pm 0.39$ \\
\hline
\end{tabular}

${ }^{a}$ Data are mean \pm SEM. 
In this study, Gad67 promoter hypomethylation with upregulation of Gad67 expression was detected in the ACC of Fabp3 KO mice. Epigenetic modifications are closely associated with various dietary factors, including methyl donors, such as folic acid, vitamin $B_{12}$, choline, and PUFAs (Milagro et al., 2013). Dietary intake of fish oil rich in docosahexaenoic acid leads to increased levels of MET adenosyl transferase and cystathionine- $\gamma$-lyase, key enzymes involved in MET metabolism, in rats (Huang et al., 2010). $n$-3 PUFAs also increase in vitro levels of cystathionine- $\gamma$ lyase and 5-methyltetrahydrofolate reductase, key enzymes involved in the homocysteine degradation pathway of MET metabolism (Huang et al., 2012). Considering that dietary PUFAs, particularly $n-6$ PUFAs, are transported into the brain by FABP3 (Murphy et al., 2005), it is possible that, through altered MET metabolism, alterations in PUFA uptake and homeostasis in $\mathrm{PV}^{+}$interneurons of the ACC underlie the epigenetic changes in the Gad67 promoter and abnormal behaviors in Fabp3 KO mice. Indeed, Fabp3 KO mice exhibit reduced incorporation of n-6 PUFAs into brain phospholipids (Murphy et al., 2005). Therefore, it is likely that a decrease in $n-6$ PUFA content is associated with epigenetic changes in $\mathrm{PV}^{+}$interneurons of Fabp3 $\mathrm{KO}$ mice. However, in the current study, we did not observe a reduction in SAM levels in the ACC of Fabp3 KO mice, although we did find that overexpression of Fabp3 increased SAM levels in differentiated Neuro-2A cells. Because FABP3 plays an important role in fetal development through the regulation of $n-3$ and $n-6$ PUFA transport (Islam et al., 2014), we speculate that dynamic changes in SAM concentrations may occur during early life stages. In the human cerebral cortex, a robust and progressive rise in DNA methylation levels across the lifespan was observed for the GAD67 gene, typically in conjunction with declining mRNA levels (Siegmund et al., 2007). Therefore, it is suggested that FABP3 directly regulates MET metabolism, including SAM synthesis, thereby regulating DNA methylation status during the perinatal period. In future studies, we plan to measure DNA methylation and MET metabolism in the ACCs of fetal and juvenile mice.

The present study has an important limitation in that we focused on the methylation status of a single gene promoter, Gad67. Indeed, it has been reported that $n$-3 PUFA supplementation leads to changes in the expression of various genes, including calmodulin and protein phosphatase $2 \mathrm{~A}$, which play important roles in synaptic plasticity (Kitajka et al., 2002, 2004). In particular, protein phosphatase $2 \mathrm{~A}$ dephosphorylates CaMKIV and acts as a negative regulator of CaMKIV/CREB signaling (Westphal et al., 1998). Moreover, PUFAs have roles in regulating ion channel activity (Kang and Leaf, 1996; Vreugdenhil et al., 1996). Therefore, FABP3 may indirectly regulate excitatory synaptic plasticity in the brain, including the ACC. Furthermore, prenatal $n-3$ PUFA deficiency increases the DNA methylation of the Bdnf promoter in the adult mouse brain (Fan et al., 2016). Therefore, additional studies will be necessary to confirm whether, in addition to the Gad67 promoter, there are other promoters that are the targets of FABP3 in $\mathrm{PV}^{+}$interneurons of the ACC.

Protracted treatment with MET successfully reversed Gad67 promoter hypomethylation in the ACC of Fabp3 KO mice and their abnormal novelty-seeking behaviors. We showed that chronic MET treatment increased the methylation of the Gad67 promoter and the binding of repressor complexes, such as MeCP2 and HDAC1, to this region (Dong et al., 2005, 2007). Furthermore, MET treatment in mice affected their social interaction behaviors (Tremolizzo et al., 2005). Although the cellular and molecular mechanisms that underlie how MET treatment restores the phenotypes caused by $\mathrm{FABP} 3$ deficiency remain elusive, Fabp $3 \mathrm{KO}$ mice are a useful animal model for exploring the epigenetic involvement in the pathomechanism of various psychiatric diseases with abnormal behaviors.

\section{References}

Amemori K, Graybiel AM (2012) Localized microstimulation of primate pregenual cingulate cortex induces negative decision-making. Nat Neurosci 15:776-785. CrossRef Medline

Archer J (1973) Tests for emotionality in rats and mice: a review. Anim Behav 21:205-235. CrossRef Medline

Asada H, Kawamura Y, Maruyama K, Kume H, Ding RG, Kanbara N, Kuzume H, Sanbo M, Yagi T, Obata K (1997) Cleft palate and decreased brain gamma-aminobutyric acid in mice lacking the $67-\mathrm{kDa}$ isoform of glutamic acid decarboxylase. Proc Natl Acad Sci U S A 94:6496-6499. CrossRef Medline

Bali P, Im HI, Kenny PJ (2011) Methylation, memory and addiction. Epigenetics 6:671-674. Medline

Binas B, Danneberg H, McWhir J, Mullins L, Clark AJ (1999) Requirement for the heart-type fatty acid binding protein in cardiac fatty acid utilization. FASEB J 13:805-812. CrossRef Medline

Bonanna G, Fassio A, Schmid G, Severi P, Sala R, Raiteri M (1997) Pharmacologically distinct GABAB receptors that mediate inhibition of GABA and glutamate release in human neocortex. Br J Pharmacol 120:60-64. CrossRef Medline

Bush G, Frazier JA, Rauch SL, Seidman LJ, Whalen PJ, Jenike MA, Rosen BR, Biederman J (1999) Anterior cingulate cortex dysfunction in attentiondeficit/hyperactivity disorder revealed by fMRI and the counting stroop. Biol Psychiatry 45:1542-1552. CrossRef Medline

Bush G, Luu P, Posner MI (2000) Cognitive and emotional influences in anterior cingulate cortex. Trends Cogn Sci 4:215-222. CrossRef Medline

Bush G, Vogt BA, Holmes J, Dale AM, Greve D, Jenike MA, Rosen BR (2002) Dorsal anterior cingulate cortex: a role in reward-based decision making. Proc Natl Acad Sci U S A 99:523-528. CrossRef Medline

Chew YC, Adhikary G, Wilson GM, Xu W, Eckert RL (2012) Sulforaphane induction of $\mathrm{p} 21$ (Cip1) cyclin-dependent kinase inhibitor expression requires p53 and Sp1 transcription factors and is p53-dependent. J Biol Chem 287:16168-16178. CrossRef Medline

Devinsky O, Morrell MJ, Vogt BA (1995) Contributions of anterior cingulate cortex to behaviour. Brain 118:279-306. CrossRef Medline

Di Martino A, Ross K, Uddin LQ, Sklar AB, Castellanos FX, Milham MP (2009) Functional brain correlates of social and nonsocial processes in autism spectrum disorders: an activation likelihood estimation metaanalysis. Biol Psychiatry 65:63-74. CrossRef Medline

Dong E, Agis-Balboa RC, Simonini MV, Grayson DR, Costa E, Guidotti A (2005) Reelin and glutamic acid decarboxylase67 promoter remodeling in an epigenetic methionine-induced mouse model of schizophrenia. Proc Natl Acad Sci U S A 102:12578-12583. CrossRef Medline

Dong E, Guidotti A, Grayson DR, Costa E (2007) Histone hyperacetylation induces demethylation of reelin and 67-kDa glutamic acid decarboxylase promoters. Proc Natl Acad Sci U S A 104:4676-4681. CrossRef Medline

Ebrahimi M, Yamamoto Y, Sharifi K, Kida H, Kagawa Y, Yasumoto Y, Islam A, Miyazaki H, Shimamoto C, Maekawa M, Mitsushima D, Yoshikawa T, Owada Y (2016) Astrocyte-expressed FABP7 regulates dendritic morphology and excitatory synaptic function of cortical neurons. Glia 64:4862. CrossRef Medline

Elliott E, Manashirov S, Zwang R, Gil S, Tsoory M, Shemesh Y, Chen A (2016) Dnmt3a in the medial prefrontal cortex regulates anxiety-like behavior in adult mice. J Neurosci 36:730-740. CrossRef Medline

Ennaceur A, Neave N, Aggleton JP (1997) Spontaneous object recognition and object location memory in rats: the effects of lesions in the cingulate cortices, the medial prefrontal cortex, the cingulum bundle and the fornix. Exp Brain Res 113:509-519. CrossRef Medline

Fan C, Fu H, Dong H, Lu Y, Qi K (2016) Maternal $n$-3 polyunsaturated fatty acid deprivation during pregnancy and lactation affects neurogenesis and apoptosis in adult offspring: associated with DNA methylation of brainderived neurotrophic factor transcripts. Nutr Res 36:1013-1021. CrossRef Medline

File SE, Wardill AG (1975) Validity of head-dipping as a measure of exploration in a modified hole-board. Psychopharmacologia 44:53-59. CrossRef Medline

Fitzgerald KD, Welsh RC, Gehring WJ, Abelson JL, Himle JA, Liberzon I, 
Taylor SF (2005) Error-related hyperactivity of the anterior cingulate cortex in obsessive-compulsive disorder. Biol Psychiatry 57:287-294. CrossRef Medline

Frankland PW, Bontempi B, Talton LE, Kaczmarek L, Silva AJ (2004) The involvement of the anterior cingulate cortex in remote contextual fear memory. Science 304:881-883. CrossRef Medline

Furuhashi M, Hotamisligil GS (2008) Fatty acid-binding proteins: role in metabolic diseases and potential as drug targets. Nat Rev Drug Discov 7:489-503. CrossRef Medline

Gassmann M, Bettler B (2012) Regulation of neuronal GABA(B) receptor functions by subunit composition. Nat Rev Neurosci 13:380-394. CrossRef Medline

Higley MJ (2014) Localized GABAergic inhibition of dendritic $\mathrm{Ca}(2+)$ signalling. Nat Rev Neurosci 15:567-572. CrossRef Medline

Hladnik A, Dzaja D, Darmopil S, Jovanov-Milosevic N, Petanjek Z (2014) Spatio-temporal extension in site of origin for cortical calretinin neurons in primates. Front Neuroanat 8:50. CrossRef Medline

Huang T, Wahlqvist ML, Li D (2010) Docosahexaenoic acid decreases plasma homocysteine via regulating enzyme activity and mRNA expression involved in methionine metabolism. Nutrition 26:112-119. CrossRef Medline

Huang T, Wahlqvist ML, Li D (2012) Effect of $n-3$ polyunsaturated fatty acid on gene expression of the critical enzymes involved in homocysteine metabolism. Nutr J 11:6. CrossRef Medline

Isaacson JS, Hille B (1997) $\mathrm{GABA}_{\mathrm{B}}$-mediated presynaptic inhibition of excitatory transmission and synaptic vesicle dynamics in cultured hippocampal neurons. Neuron 18:143-152. CrossRef Medline

Islam A, Kagawa Y, Sharifi K, Ebrahimi M, Miyazaki H, Yasumoto Y, Kawamura S, Yamamoto Y, Sakaguti S, Sawada T, Tokuda N, Sugino N, Suzuki $\mathrm{R}$, Owada Y (2014) Fatty acid binding protein 3 is involved in $n-3$ and n-6 PUFA transport in mouse trophoblasts. J Nutr 144:1509-1516. CrossRef Medline

Johansen JP, Fields HL (2004) Glutamatergic activation of anterior cingulate cortex produces an aversive teaching signal. Nat Neurosci 7:398-403. CrossRef Medline

Johansen JP, Fields HL, Manning BH (2001) The affective component of pain in rodents: direct evidence for a contribution of the anterior cingulate cortex. Proc Natl Acad Sci U S A 98:8077-8082. CrossRef Medline

Kang JX, Leaf A (1996) Evidence that free polyunsaturated fatty acids modify $\mathrm{Na}^{+}$channels by directly binding to the channel proteins. Proc Natl Acad Sci U S A 93:3542-3546. CrossRef Medline

Kasahara J, Fukunaga K, Miyamoto E (1999) Differential effects of a calcineurin inhibitor on glutamate-induced phosphorylation of $\mathrm{Ca}^{2+}$ / calmodulin-dependent protein kinases in cultured rat hippocampal neurons. J Biol Chem 274:9061-9067. CrossRef Medline

Kida H, Tsuda Y, Ito N, Yamamoto Y, Owada Y, Kamiya Y, Mitsushima D (2016) Motor training promotes both synaptic and intrinsic plasticity of layer II/III pyramidal neurons in the primary motor cortex. Cereb Cortex 26:3494-3507. CrossRef Medline

Kitajka K, Puskás LG, Zvara A, Hackler L Jr, Barceló-Coblijn G, Yeo YK, Farkas T (2002) The role of $n-3$ polyunsaturated fatty acids in brain: modulation of rat brain gene expression by dietary $n$ - 3 fatty acids. Proc Natl Acad Sci U S A 99:2619-2624. CrossRef Medline

Kitajka K, Sinclair AJ, Weisinger RS, Weisinger HS, Mathai M, Jayasooriya AP, Halver JE, Puskás LG (2004) Effects of dietary omega-3 polyunsaturated fatty acids on brain gene expression. Proc Natl Acad Sci U S A 101:10931-10936. CrossRef Medline

Kundakovic M, Chen Y, Costa E, Grayson DR (2007) DNA methyltransferase inhibitors coordinately induce expression of the human reelin and glutamic acid decarboxylase 67 genes. Mol Pharmacol 71:644-653. CrossRef Medline

Kundakovic M, Chen Y, Guidotti A, Grayson DR (2009) The reelin and GAD67 promoters are activated by epigenetic drugs that facilitate the disruption of local repressor complexes. Mol Pharmacol 75:342-354. CrossRef Medline

Li DP, Chen SR, Pan YZ, Levey AI, Pan HL (2002) Role of presynaptic muscarinic and $\mathrm{GABA}(\mathrm{B})$ receptors in spinal glutamate release and cholinergic analgesia in rats. J Physiol 543:807-818. CrossRef Medline

Liu RZ, Li X, Godbout R (2008) A novel fatty acid-binding protein (FABP) gene resulting from tandem gene duplication in mammals: transcription in rat retina and testis. Genomics 92:436-445. CrossRef Medline

Manabe T, Tatsumi K, Inoue M, Matsuyoshi H, Makinodan M, Yokoyama S,
Wanaka A (2005) L3/Lhx8 is involved in the determination of cholinergic or GABAergic cell fate. J Neurochem 94:723-730. CrossRef Medline

Matrisciano F, Tueting P, Dalal I, Kadriu B, Grayson DR, Davis JM, Nicoletti F, Guidotti A (2013) Epigenetic modifications of GABAergic interneurons are associated with the schizophrenia-like phenotype induced by prenatal stress in mice. Neuropharmacology 68:184-194. CrossRef Medline

Milagro FI, Mansego ML, De Miguel C, Martínez JA (2013) Dietary factors, epigenetic modifications and obesity outcomes: progresses and perspectives. Mol Aspects Med 34:782-812. CrossRef Medline

Miller CA, Gavin CF, White JA, Parrish RR, Honasoge A, Yancey CR, Rivera IM, Rubio MD, Rumbaugh G, Sweatt JD (2010) Cortical DNA methylation maintains remote memory. Nat Neurosci 13:664-666. CrossRef Medline

Mitsushima D, Sano A, Takahashi T (2013) A cholinergic trigger drives learning-induced plasticity at hippocampal synapses. Nat Commun 4:2760. CrossRef Medline

Murphy EJ, Owada Y, Kitanaka N, Kondo H, Glatz JF (2005) Brain arachidonic acid incorporation is decreased in heart fatty acid binding protein gene-ablated mice. Biochemistry 44:6350-6360. CrossRef Medline

Owada Y, Yoshimoto T, Kondo H (1996) Spatio-temporally differential expression of genes for three members of fatty acid binding proteins in developing and mature rat brains. J Chem Neuroanat 12:113-122. CrossRef Medline

Paxinos G, Franklin KBJ (2004) The mouse brain in stereotaxic coordinates. Cambridge, MA: Academic Press.

Pezze MA, Marshall HJ, Fone KC, Cassaday HJ (2017) Role of the anterior cingulate cortex in the retrieval of novel object recognition memory after a long delay. Learn Mem 24:310-317. CrossRef Medline

Rost BR, Nicholson P, Ahnert-Hilger G, Rummel A, Rosenmund C, Breustedt J, Schmitz D (2011) Activation of metabotropic GABA receptors increases the energy barrier for vesicle fusion. J Cell Sci 124:3066-3073. CrossRef Medline

Sato A, Shibuya H (2013) WNK signaling is involved in neural development via Lhx8/Awh expression. PLoS One 8:e55301. CrossRef Medline

Shimamoto C, Ohnishi T, Maekawa M, Watanabe A, Ohba H, Arai R, Iwayama $\mathrm{Y}$, Hisano $\mathrm{Y}$, Toyota T, Toyoshima M, Suzuki K, Shirayama $\mathrm{Y}$, Nakamura K, Mori N, Owada Y, Kobayashi T, Yoshikawa T (2014) Functional characterization of FABP3, 5 and 7 gene variants identified in schizophrenia and autism spectrum disorder and mouse behavioral studies. Hum Mol Genet 23:6495-6511. CrossRef Medline

Shioda N, Yamamoto Y, Watanabe M, Binas B, Owada Y, Fukunaga K (2010) Heart-type fatty acid binding protein regulates dopamine D2 receptor function in mouse brain. J Neurosci 30:3146-3155. CrossRef Medline

Shioda N, Yabuki Y, Kobayashi Y, Onozato M, Owada Y, Fukunaga K (2014) FABP3 protein promotes alpha-synuclein oligomerization associated with 1-methyl-1,2,3,6-tetrahydropiridine-induced neurotoxicity. J Biol Chem 289:18957-18965. CrossRef Medline

Siegmund KD, Connor CM, Campan M, Long TI, Weisenberger DJ, Biniszkiewicz D, Jaenisch R, Laird PW, Akbarian S (2007) DNA methylation in the human cerebral cortex is dynamically regulated throughout the life span and involves differentiated neurons. PLoS One 2:e895. CrossRef Medline

Stadler C, Sterzer P, Schmeck K, Krebs A, Kleinschmidt A, Poustka F (2007) Reduced anterior cingulate activation in aggressive children and adolescents during affective stimulation: association with temperament traits. J Psychiatr Res 41:410-417. CrossRef Medline

Szechtman H, Woody E (2004) Obsessive-compulsive disorder as a disturbance of security motivation. Psychol Rev 111:111-127. CrossRef Medline

Szyf M (2015) Prospects for the development of epigenetic drugs for CNS conditions. Nat Rev Drug Discov 14:461-474. CrossRef Medline

Tamamaki N, Yanagawa Y, Tomioka R, Miyazaki J, Obata K, Kaneko T (2003) Green fluorescent protein expression and colocalization with calretinin, parvalbumin, and somatostatin in the GAD67-GFP knock-in mouse. J Comp Neurol 467:60-79. CrossRef Medline

Tremolizzo L, Doueiri MS, Dong E, Grayson DR, Davis J, Pinna G, Tueting P, Rodriguez-Menendez V, Costa E, Guidotti A (2005) Valproate corrects the schizophrenia-like epigenetic behavioral modifications induced by methionine in mice. Biol Psychiatry 57:500-509. CrossRef Medline

Uematsu M, Hirai Y, Karube F, Ebihara S, Kato M, Abe K, Obata K, Yoshida S, Hirabayashi M, Yanagawa Y, Kawaguchi Y (2008) Quantitative chem- 
ical composition of cortical GABAergic neurons revealed in transgenic venus-expressing rats. Cereb Cortex 18:315-330. CrossRef Medline

Vreugdenhil M, Bruehl C, Voskuyl RA, Kang JX, Leaf A, Wadman WJ (1996) Polyunsaturated fatty acids modulate sodium and calcium currents in CA1 neurons. Proc Natl Acad Sci U S A 93:12559-12563. CrossRef Medline

Watanabe K, Wakabayashi H, Veerkamp JH, Ono T, Suzuki T (1993) Immunohistochemical distribution of heart-type fatty acid-binding protein immunoreactivity in normal human tissues and in acute myocardial infarct. J Pathol 170:59-65. CrossRef Medline

Weible AP, Rowland DC, Pang R, Kentros C (2009) Neural correlates of novel object and novel location recognition behavior in the mouse anterior cingulate cortex. J Neurophysiol 102:2055-2068. CrossRef Medline

Weible AP, Rowland DC, Monaghan CK, Wolfgang NT, Kentros CG (2012) Neural correlates of long-term object memory in the mouse anterior cingulate cortex. J Neurosci 32:5598-5608. CrossRef Medline
Westphal RS, Anderson KA, Means AR, Wadzinski BE (1998) A signaling complex of $\mathrm{Ca}^{2+}$-calmodulin-dependent protein kinase IV and protein phosphatase 2A. Science 280:1258-1261. CrossRef Medline

Yabuki Y, Takahata I, Matsuo K, Owada Y, Fukunaga K (2018) Ramelteon improves post-traumatic stress disorder-like behaviors exhibited by fatty acid-binding protein 3 null mice. Mol Neurobiol 55:3577-3591. CrossRef Medline

Yamamoto Y, Shioda N, Han F, Moriguchi S, Nakajima A, Yokosuka A, Mimaki Y, Sashida Y, Yamakuni T, Ohizumi Y, Fukunaga K (2009) Nobiletin improves brain ischemia-induced learning and memory deficits through stimulation of CaMKII and CREB phosphorylation. Brain Res 1295:218-229. CrossRef Medline

Yamamoto Y, Shioda N, Han F, Moriguchi S, Fukunaga K (2013) Novel cognitive enhancer ST101 enhances acetylcholine release in mouse dorsal hippocampus through T-type voltage-gated calcium channel stimulation. J Pharmacol Sci 121:212-226. CrossRef Medline 